Homoki-Nagy Mária

\title{
A BÍRÓI FELELŐSSÉG KÉRDÉSÉNEK MEGÍTÉLÉSE A GYAKORLATBAN ${ }^{1}$
}

\author{
The Assessment of the Responsibility of Judges in Practice
}

Prof. Dr. Homoki-Nagy Mária egyetemi tanár, tanszékvezető, Szegedi Tudományegyetem Állam- és Jogtudományi Kar Magyar Jogtörténeti Tanszék, homoki@juris.u-szeged.hu

Az 1871: VIII. tc. rendelkezett a bírák fegyelmi felelösségéröl. A fegyelmi vétség két nagy csoportját határozta meg, az egyiket az úgynevezett hivatali büntettek képezték, amelyeknek a körét a törvény taxatíve felsorolta. Ebben az esetben rendes büntetöeljárást kellett inditani. A fegyelmi vétségek másik körét a hivatali kötelességszegések alkották. A tényleges szabályszegés mellett idetartoztak mindazon cselekmények, amelyekkel a biróság tekintélyét, a bíróságba vetett bizalmat csorbitotta valaki. A Szegedi Ítélőtábla fennmaradt iratai között a szerző arra kereste a választ, mely cselekményeket minösitettek olyannak, amelyek esetében fegyelmi vétséget a fegyelmi bíróság megállapitott. A feltárt levéltári források alapján a bírák által betartandó ügyrendi szabályok megsértése, jegyzőkönyvek aláírásának elmaradása volt a leggyakoribb. A bíróság tekintélyének a csorbitását azok a cselekmények képezték, amelyek esetében a kor erkölcsi szabályainak a megsértését állapitották meg.

A források alapján megállapitható, hogy írásbeli figyelmeztetés vagy feddés a legtöbb esetben elegendö volt, néhány súlyosabb esetben pénzbüntetést szabtak ki, esetleg az áthelyezés kivételes eszközét alkalmazták.

\section{KulcsszavaK:}

bírói felelősség, fegyelmi vétség, kötelességszegés, erkölcsi magatartás, a bíró áthelyezése

\footnotetext{
A mű a KÖFOP-2.1.2-VEKOP-15-2016-00001 azonosító számú „A jó kormányzást megalapozó közszolgálat-fejlesztés" elnevezésű kiemelt projekt keretében működtetett Államtudományi Kutatóműhely keretében, a Nemzeti Közszolgálati Egyetem felkérésére készült.
} 
Act VIII of 1871 regulated the disciplinary responsibility of judges. Two categories of disciplinary offences were determined by the legislator. One group was the malfeasances, which were enumerated by the act itemised. If somebody committed a malfeasance, which was specified by this paragraph of the act, criminal procedure had to be started against him, consequently these actions were offences. The other group of disciplinary offences according to the act was infringements while in office. This category included actions when the judge failed in his duty, but did not want to cause damage purposely. Nevertheless, all the actions were infringements while in office which impaired the prestige of court and confidence in court. We are not able to determine these infringements exactly on the basis of the act, therefore the author examined the documents of the Court of Appeal in Szeged, in which cases the disciplinary court stated facts of disciplinary offences.

\section{KeYwords:}

responsability of judges, jurisdiction, criminal procedure, infringement, Court of Appeal 


\section{BEVEZETŐ}

A kiegyezési törvényeket követő törvényalkotási munkák között jelentős szerepet töltöttek be az igazságszolgáltatás szervezetét és működését meghatározó törvények, amelyek közül kiemelkedik az 1869: IV. tc., amely a közigazgatás és a bírói hatalom szétválasztása mellett először rendelkezett a bíróvá válás feltételeiről, a bírói függetlenségröl és a bírói összeférhetetlenség kérdéséről. ${ }^{2}$ Ezt egészítette ki az 1871: VIII. tc., amely a bírói felelősség kérdését, illetve az erre vonatkozó eljárási szabályokat rögzítette. Az alkotmányos államberendezkedés kiépítésének folyamatában a bírói függetlenség alapelvének rögzítése mellett szükségessé vált egyrészt annak kimondása, hogy a bírák és a bírósági hivatalnokok kötelessége a törvények betartása és betartatása, másrészt hangsúlyozni kellett, hogy a törvényekben meghatározott módon kell igazságszolgáltatási tevékenységüket ellátni. A felelősség szempontjából a törvény különbséget tett a között, hogy hivatali büntettet vagy fegyelmi vétséget követett-e el valaki.

Azon cselekményeket, amelyek alapján a bíró felelőssége megállapítható volt két csoportba sorolta a jogalkotó. Az egyik csoportot a hivatali büntettek képezték, amelyet akkor lehetett megállapítani, ha a bíró vagy a bírósági hivatalnok azzal a tudattal követte el cselekményét, hogy „magának vagy másoknak illetéktelen hasznot szerezzen, vagy valakinek jogtalan kárt okozzon” [1871: VIII. tc. 10. \$]. ${ }^{3}$ Ezen túlmenően a törvény taxatíve felsorolta azokat a büncselekményeket - a hivatali titok közlése, a megvesztegettetés, a zsarolás, az erőszak, a hamisítás és a sikkasztás -, amelyek elkövetése esetén a hivatali büntett megállapítást nyerhetett. Ha a hivatali büntett elkövetésének gyanúja felmerült, akkor rendes bünvádi eljárást kellett lefolytatni. ${ }^{4}$ Ezzel szemben a másik csoportba a fegyelmi vétségek tartoztak, amelyeket az követett el, „[a] ki hivatali kötelességét vétkesen, de nem azon bünös czélból szegi meg, hogy ez által magának vagy másnak illetéktelen hasznot szerezzen, vagy valakinek jogtalan kárt okozzon; [a] ki botrányos magaviselete miatt tiszteletre s bizalomra méltatlanná válik" [1871: VIII. tc. 20. \$]. ${ }^{5}$ Dogmatikailag jól elhatárolható a két cselekménycsoport közötti különbség, hiszen a hivatali büntettet a bíró vagy a bírósági hivatalnok az illetéktelen haszonszerzés és a jogtalan károkozás szándékával követhette el, ezzel szemben a fegyelmi vétség esetében ez a tudati magatartás hiányzik. Itt a hivatali kötelességszegésre helyezte a hangsúlyt a jogalkotó, illetve minden olyan emberi magatartásra, amelynek megítélése a társadalom részéről megbotránkozást keltett, ahogy egyes konkrét esetekben meghatározták: az elkövetett magatartás alkalmas arra,

2 Máthé Gábor: A magyar burzsoá igazságszolgáltatási szervezet kialakulása 1867-1875. Budapest, Akadémiai Kiadó, 1982.; Stipta István: A magyar bírósági rendszer története. Multiplex Media, Debrecen, 1997; HomokiNagy Mária: A bírói felelősség az 1869:IV. tc. alapján. Acta Universitatis Szegediensis: Forum: Acta Juridica et Politica, 7. (2017), 1. 45-68.

Máthé (1982) i. m. 56.; 1871: VIII. tc. 10.

4 Székely Miksa: A bírák és bírói hivatalnokok felelösségéröl szóló törvényjavaslat. Magyar Jogászegyleti Értekezések XLIII. V. kötet, (1989), 2. 22-23.

Máthé (1982) i. m. 56.; Navratil Szonja: A jogászi hivatásrendek története Magyarországon (1868/1869-1937). Budapest, ELTE Eötvös, 2014. 59-60.; 1871: VIII. tc. 20. \$. 
„hogy a társadalomban megbotránkozást keltsen”. ${ }^{6}$ Éppen ezért a fegyelmi vétség körébe tartozó magatartási formákat nem lehetett - ma sem lehet - taxatíve felsorolni. ${ }^{7}$ Minden egyes esetben azt kell, azt kellett elemzés tárgyává tenni, hogy az adott magatartás, az adott közösségben megbotránkozást vált, váltott-e ki, vagy sem. A hivatali kötelességszegés mellett tehát a bíró és a bírói hivatalnok magatartásának az erkölcsi megítélése is történt. Éppen ezért ez a magatartási kör koronként változhat, de a bíróval szemben támasztott társadalmi elvárás, amelyet az alapoz meg, hogy a bíró független, az ítélet meghozatalában senki sem befolyásolhatja, viszont köteles a törvényt betartani és betartatni, és lehetőség szerint az igazságnak megfelelően dönteni, ma is megkívánja az úgynevezett feddhetetlen magatartást. A bírótól elvárt felelős magatartás volt a garanciája a bírói függetlenségnek. ${ }^{8}$

A fegyelmi vétség fogalmának pontos tartalmi meghatározása nemcsak a törvény keletkezésének idején, hanem a 20. század elején is felmerült, amikor az 1871. évi törvény módosítására készültek. Márkus Dezső állapította meg, hogy „e fogalom meghatározása nem könnyü. Fix pont benne csak annyi, hogy fegyelmi vétség az olyan szabályellenes magatartás, cselekmény vagy mulasztás, amely nem ütközik a büntetőtörvényekbe." Márkus a francia, a svájci és a német törvények szövegét elemezve megállapítja, hogy azok sem törekszenek arra, hogy pontosan meghatározzák azokat a cselekvéseket vagy mulasztásokat, amelyekkel a fegyelmi vétség cselekménye megvalósítható lenne. Ezek a jogszabályok is megelégszenek azzal, hogy a bírák kötelezettségszegése elegendő ahhoz, hogy a fegyelmi vétséget megállapítsák. Márkus szerint a bíráktól és az ügyészektől nemcsak az várható el, hogy hivatali kötelezettségeiket teljesítsék, hanem általában az emberi magatartásuknak kell mintaszerűnek lenni. „A bíró és ügyész életének mintaszerűnek kell lennie, és korrektség szempontjából helyt kell állnia a képzelhető legszigorúbb bírálattal szemben is, mert csak így lehet jogosult embertársainak erkölcsi fogyatkozásai és gyöngeségei fölött ítélni, sőt őket azokért megbüntetni."10

Annak megértéséhez, hogy a 19-20. század fordulóján miért tekintettek a bírói felelősség szabályozására úgy, mint a bírói függetlenség garanciájára, elengedhetetlen az e területen

6 Magyar Nemzeti Levéltár Csongrád Megyei Levéltára (CSML) VII. 1. 1891-1950, Szegedi Ítélőtábla Elnöki iratok VII.1. 1896 Schnell F. esete.

Máthé (1982) i. m. 56.; Navratil Szonja a hivatali vétségeket három csoportba sorolja, de ez a csoportosítás nem az 1871: VIII. tc. rendelkezése alapján történik. Navratil (2014) i. m. 60-61. Bár az 1871: VIII. tc. 21. \$-ában a törvényalkotók meghatároztak három esetcsoportot, amelynek elkövetése a fegyelmi vétséget megalapozta, ez nem ölelhette fel azokat a magatartási formákat, amelyek megalapozhatták a fegyelmi vétség miatt elindítandó eljárásokat.

8 A törvényjavaslat képviselőházi vitáján többen kritizálták a javaslat szövegét. Ezek közé tartozott Ghyczy Kálmán, aki a bírák függetlenségét a felügyeleti hatóságoktól látta veszélyeztetve: „[M]iután ezentúl a bírák lefelé tökéletesen függetlenek lesznek, felfelé, a kormány irányában is épen úgy függetlenekké tétessenek; ezen czélnak pedig a törvényjavaslat meg nem felel, mert fennhagyja a lehetséget, hogy a kormány, melytől a bírák előléptetése függ, folytonosan beavatkozhassék a bíróságok ügyvitelébe" Tóth Lőrinc (szerk.): A birói felelősségi törvény az országgyülésen s az ügyvédi egyletekben. 441.

9 Márkus Dezső: A bírói felelősségről szóló törvény módosítása. Jogtudományi Közlöny, (1909), 41. $354-359$. 354.; lásd ehhez: Papp László: A bírák fegyelmi felelőssége a polgári korban. Kézirat.

10 Márkus (1909) i. m. 355. 
kialakult gyakorlatnak a megismerése. ${ }^{11}$ Arra nincs lehetőség e tanulmány keretei között, hogy valamennyi kir. ítélötábla kebeléből szervezett fegyelmi bíróság tevékenységét megvizsgáljam, elegendő ehhez a Szegedi Ítélőtábla elnöki iratai között fellelhető fegyelmi eljárások megismerése. ${ }^{12}$ A Szegedi Ítélőtábla és ezen belül a Szegedi törvényszék történetének feltárása során megállapítást nyert, hogy a Szegedi Ítélőtábla illetékességébe tartozó törvényszéki iratok jelentős része megsemmisült, ugyanakkor az úgynevezett elnöki iratok között egyrészt megtalálhatók az egyes bírák szoros értelemben vett személyi anyaga, másrészt bizonyos fegyelmi eljárások iratai is. Tekintettel arra, hogy ezek az ügytípusok az ítélőtábla elnökének hatáskörét képező igazgatási ügyeket érintő tevékenységét megőrző más iratok között lelhetők fel, a Szegedi Ítélőtábla illetékességébe tartozó valamennyi törvényszék és járásbíróság anyaga nem tekinthető át. A levéltári kutatások viszont lehetővé tették, hogy a bírói felelősség kérdésének gyakorlati megítélését, ezen belül elsősorban a fegyelmi vétség körébe tartozó magatartások értelmezését feltérképezzük. A meghozott ítéletek bizonyos általános megállapításokra is lehetőséget adnak, mert sok esetben, a jogorvoslati eljárások során a királyi Kúria hozta meg a jogerős ítéletet, ezért a Kúria joggyakorlata is megismerhető.

A tanulmány keretei között csak az 1871: VIII. tc. fegyelmi vétségre vonatkozó rendelkezéseinek a gyakorlati alkalmazását vizsgáltam azért, hogy az egyes konkrét esetek alapján meghatározhassam azon magatartási formákat, amelyek a fegyelmi vétség elkövetési magatartását megalapozhatták.

Az ítélőtáblák decentralizálására 1890-ben került sor, ezért a fegyelmi vétség megítélésének a vizsgálata - különös tekintettel a Szegedi királyi Ítélőtáblára - ténylegesen ettől az időponttól kutatható. ${ }^{13} \mathrm{Az}$ átvizsgált iratok között nem találtam olyan esetet, amikor hivatali bűntett miatt rendes bírósági eljárás indult volna. Ez a megállapítás nem jelenti azt, hogy nem fordulhatott elő olyan eset, amikor egy bírót vagy bírósági hivatalnokot jogtalan haszonszerzés miatt ne vontak volna büntetőeljárás alá, de a feltárt források a Szegedi Ítélőtábla iratai között erre nem utalnak. ${ }^{14}$ Navratil Szonja az általa tényleges fegyelmi ügyeknek minősített eseteknél azt állítja, hogy ezekben az esetekben „a fegyelmi hatóság

11 Különösen fontos ez azért is, mert a kiegyezést követő törvényalkotás idején, a polgári értelemben vett jogállam kialakításának kezdetén nagy figyelmet fordítottak nemcsak a bírák, bírói hivatalnokok magatartásának megítélésére, hanem a közigazgatási tisztségviselők felelősségének megállapítására is. Az 1870: XLII. tc. a köztörvényhatóságokról, valamint az 1871: XVIII. tc. a községekről ugyancsak szólt a közigazgatási tisztségviselők kártérítési felelőssége mellett a hivatali tevékenységük során elkövetett mulasztásokért járó fegyelmi felelősségről.

12 Az Igazságügyi Minisztérium iratai között fellelhető más ítélőtábláknál előforduló fegyelmi eljárásokra utalás található Máthé Gábor és Navratil Szonja monográfiáiban és Papp László kéziratában.

13 Hangsúlyozni szeretném, hogy e tanulmány keretei között csak a Szegedi Ítélőtábla illetékességébe tartozó bírák által elkövetett esetleges fegyelmi vétségek hátterét, illetve magát a fegyelmi eljárásokat elemzem. Ezért adatokat csak 1890-től lehet levéltári források alapján feltárni. 1871-1890 közötti időszakra Máthé Gábor és Navratil Szonja munkáiban található utalás.

14 Navratil Szonja a fegyelmi ügyeket három csoportba sorolta: 1. fegyelmi ügyek, mint fellebbezések; 2. tényleges fegyelmi ügyek; 3. azok a fegyelmi ügyek, ahol a politikai történések tetten érhetőek. A tényleges fegyelmi ügyek között utal olyan esetekre, amikor bíró által elkövetett bűncselekmény miatt indult fegyelmi eljárás. Navratil (2014) i. m. 60-61. és 132-133. 
kivétel nélkül megállapította a bepanaszolt bíró vétkességét, ám ennek feltehetőleg nem a bírói kar hivatásbeli etikai tudatossága volt az oka, hanem az, hogy a tényleges fegyelmi ügyek között sok volt a bíró által elkövetett bűncselekmény. Büncselekmény esetén pedig a fegyelmi eljárás megalapozottsága nem lehetett kétséges. ${ }^{{ }^{15}} \mathrm{~A}$ szerző által vizsgált levéltári források valószínűleg sok olyan ügyet őriztek meg, ahol a fegyelmi eljárást egy, a bíró által elkövetett büncselekmény alapozta meg. A Szegedi Ítélőtábla területén ilyen megállapítást nem lehet tenni. Sőt, fegyelmi eljárásra az általam vizsgált évtizedekben csak az 1871: VIII. tc. 20. \$-ában foglalt hivatali kötelezettségszegések miatt került sor elsősorban.

Az 1871: VIII. tc. 20. $\$$ a) pontja rendelkezik a fegyelmi vétség azon változatáról, amikor a bíró hivatali kötelezettségét vétkesen szegte meg, a b) pontban pedig a bíró „botrányos magaviseletéről”, amely ténylegesen a bíróság tekintélyét, az igazságszolgáltatásba vetett bizalom csökkenését eredményezte.

Tekintettel arra, hogy a törvény rendelkezése értelmében a fegyelmi vétség tartalmát csak mint hivatali kötelezettségszegést lehetett megállapítani, érdemes azt megvizsgálni, hogy a mindennapok gyakorlatában végső soron mit tekintettek hivatali kötelezettségszegésnek és mit olyan „csekélyebb rendetlenségnek”, amely legfeljebb a figyelmeztetés körébe esett (1871: VIII. tc. 28. \$).

Az 1871. évi törvény javaslatának tárgyalásakor a képviselőházi vitában többek, annak a félelmüknek adtak hangot, hogy a bírákat alaptalan támadásoknak teszi ki a törvény a peres felek vagy éppen az ügyvédek részéről. ${ }^{16}$ Felvetödik a kérdés, hogy mennyiben volt megalapozott ez a félelem. Ehhez azonban érdemes néhány konkrét ügyet megvizsgálni, ami azért is lényeges, mert csak így lehet megállapítani, hogy a gyakorlatban mit ítéltek meg olyan kötelességszegésnek, amely fegyelmi vétségnek minősült.

\section{AZ ELJÁRÁSI SZABÁLYOK MEGSÉRTÉSE}

1896. január 22-én történt az az eset, amikor a csendőrség arra kérte az illetékes járásbíróság albíróját, aki egyébként vizsgálóbírói feladatokat is ellátott, hogy egy gyilkosság gyanúsítottjait helyezze el a járásbíróság fogdájában. Az ezt követő napon a csendőrség pontosan meg nem határozott nyomozati cselekmények elvégzése miatt, a fogházból elkérte a gyanúsítottakat. Ezt az albíró megengedte. Minderről a gyanúsítottak ügyvédjét nem értesítették, aki panaszt emelt a járásbíróság vezetőjénél. A panasz tartalmazta egyrészt, hogy a gyanúsítottak a nyomozás során 6-8 napon belül gyógyuló sérüléseket szereztek,

Navratil (2014) i. m. 62.

Az így előforduló ügyeket sorolta Navratil Szonja a „fegyelmi ügyek mint fellebbezés” kategóriájába. A Szegedi İtélötábla gyakorlatában egy esetet találtam, amikor a felet képviselő ügyvéd olyan szavakkal illette az eljáró bírót, ami ha igaz, a fegyelmi vétség tényállását kimerítette volna. Ezért a bíró saját maga ellen kérte a fegyelmi eljárás megindítását. Mivel a törvény ezt nem tette lehetővé, ezt a törvényszék elutasította. Ugyanakkor az ügyvéd sem emelt panaszt a bíró ellen. Magyar Nemzeti Levéltár Csongrád Megyei Levéltára (CSML) Szegedi Îtélőtábla Elnöki iratok VII.1.8. doboz. 
amelyeket orvosi látlelettel bizonyítottak, valamint azt a tényt, hogy az eljáró vizsgálóbíró anélkül utasította a fogházőrt a gyanúsítottak elzárására, hogy a szabályszerü kihallgatásról határozatot hozott volna. Sőt, az újabb nyomozati cselekményekről sem készített feljegyzést, és a gyanúsítottak elzárásáról csak 1896. január 25-én adta ki határozatát. Az ügyvéd állítása szerint a vizsgálóbíró megszegte a büntető ügyviteli szabályokat, különösen azt, amely kimondta: „a vizsgálóbíró köteles az elővezetett terheltek letartóztatása felől azonnal határozni és azt a kir. ügyészséggel közölni” ${ }^{17} \mathrm{Az}$ ügyvédi panasz alapján megindult fegyelmi eljárásban az ügyészség is arra az álláspontra helyezkedett, hogy a vizsgálóbíró kötelezettségszegést követett el, mert a terheltek fogházban való elhelyezéséről, azok kihallgatásáról nem készített azonnal jegyzőkönyvet, a csendőrség által végzett nyomozati cselekményt, valamint azt, hogy a terhelteket ez ügyben újból kiadta a csendőrségnek elhallgatta. Ezáltal lehetetlenné tette, hogy a járásbíróság vezetője teljesíthesse azt a kötelezettségét, hogy a terhelteket azonnal kihallgathassa és a szükséges intézkedéseket megtegye. Az ügyészség ugyanakkor már a vádiratban megfogalmazta, hogy az adott esetben a vizsgálóbíró „hivatali buzgóságból” szegte meg kötelezettségét, de ez a mulasztás tette lehetővé, hogy a vezető járásbíró sem tehette meg azokat az intézkedéseket, amelyeket a terheltek fogházban való elhelyezése és a nyomozati cselekmények ellenőrzése miatt meg kellett volna tennie.

A fegyelmi eljárás során a vizsgálóbíró azzal védekezett, hogy a csendőrség a terhelteket megfelelő szoba hiányában csak megőrzés végett hozta a járásbíróság fogdájába. A megőrzés ideje alatt a csendőrség rendelkezett a terheltekkel. Az eljárás alá vont albíró védője viszont érdekes indokkal állt elő védence érdekében. Állítása szerint hivatali kötelességszegést és ebből kifolyólag fegyelmi vétséget csak akkor lehet megállapítani, ha az elkövető vétkes, de legalább súlyos hanyagság terheli. A konkrét esetben azonban „nem fordult elő hivatali kötelezettségszegés, mert a sárga könyv, sem törvény sem törvényes rendelet erejével nem bír, bűnvádi eljárásunk annyira hézagos, hogy annak alapján védencem ellen vádat emelni nem lehet". ${ }^{18}$

Amikor a konkrét eset történt, még nem léptették hatályba a Bünvádi perrendtartásról szóló 1896: XXXIII. törvényt. Az Ideiglenes Törvénykezési Szabályok hatályon kívül helyezte 1861-ben az osztrák bünvádi perrendtartást, és a kiegyezést követően Csemegi Károly kapott megbízást arra, hogy az ügyészség számára készítsen egy „ügyrendet”, amelyet egységesen lehet alkalmazni az ország egész területén. Ezt a munkát nevezték borítójáról Sárga könyvnek, amelyet iránymutatásként nemcsak az ügyészségek, hanem a bíróságok is megkaptak. A Sárga könyv nem tekinthető jogforrásnak, „csak” magánmunka volt, amelyet éppen a törvény hiánya miatt általános zsinórmértékül használtak. Erre vonatkozott az ügyvéd megállapítása, hogy nem lehet jogszabálysértés címén fegyelmi eljárást indítani, ha nincs jogszabály. ${ }^{19}$ Az első fokon eljárt fegyelmi bíróság nem fogadta

CSML Szegedi Îtélőtábla Elnöki iratok VII.1. 14. doboz S. K.

CSML Szegedi Ítélőtábla Elnöki iratok VII.1. 14. doboz.

A híres tiszaeszlári pernél is ez volt az egyik gond, hogy a Sárga könyvbe foglalt szabályok nem voltak elegendők arra, hogy eljárásjogilag teljesen biztos alapokon megállhasson a vád. Vö. Stipta István: A tiszaeszlári 
el a védőnek ezt az érvelését, és az 1871: VIII. tc. 20. \$a) pontja alapján vétkesnek mondta ki az albírót hivatali kötelezettségének megszegése miatt, és a „rosszallás” büntetését mondta ki. Fellebbezésre a Kúria kisebb fegyelmi tanácsa módosította az I. fokú fegyelmi bíróság ítéletét. Felmentette a vizsgálóbírót, de „kisebb rendetlenség” miatt az illetékes felügyeleti szervet intézkedés céljából értesítette. A Kúria elfogadta azt a védekezést, hogy a gyilkosság terheltjeit csak megőrzés végett adta át a csendőrség, és nem volt tiltó szabály arra, hogy a nyomozás kiegészítése érdekében a vizsgálóbíró a csendőrség kérésére a terhelteket kiadja. Ezért e vonatkozásban az albíró fegyelmi vétséget nem követett el. Ugyanakkor az megállapítást nyert, hogy az albíró a terhelteket, amikor a csendőrség megőrzésre a járásbíróság fogházában átadta, azonnal kihallgatta, de a terheltek vallomásáról készített jegyzőkönyvet csak három nap múlva vette fel, és csak ekkor határozott azok letartóztatásáról. A csendőrségnek úgy adta ki nyomozati cselekmények elvégzésére őket, hogy sem szóbeli, sem írásbeli határozatot erről nem hozott. Ezek a mulasztások az 1871. évi VIII. tc. 28. \$-ába ütköztek, amellyel az albíró az említett csekélyebb rendetlenség kategóriáját kimerítette. Az albíró személyi iratai őrizték meg, hogy ezért a kisebb rendetlenségért elnöki hivatali megintésben részesült.

Ugyancsak az úgynevezett előnyomozati cselekmények határozata körüli kötelezettségszegés miatt indult fegyelmi eljárás egy másik vizsgálóbíró ellen, akivel szemben az volt a vád, hogy előnyomozati határozatát csak hét év után foganatosította, amikor az ügy már elévült. Vele szemben is kötelességszegést állapítottak meg, de mivel az ügyészség nem emelt vádat, ezért a fegyelmi eljárás sem indult meg, csekélyebb rendetlenség miatt szóbeli figyelmeztetést kapott. (Ismerve egy másik esetet, amelyet az alábbiakban bemutatok, a csekélyebb rendetlenséget csak azért állapíthatták meg, mert egyszer fordult elő az érintett bíró gyakorlatában. $)^{20}$

\subsection{A jegyzökönyvezés szabályai}

Ugyancsak eljárási szabályok be nem tartása, illetve megsértése miatt indítottak fegyelmi eljárást egy törvényszéki aljegyző ellen. A vád alapját az képezte, hogy egy adósság teljesítését követelő sommás per fellebbviteli tárgyalásáról készült jegyzőkönyvben a vádlott mint a fellebbezési tanács jegyzője, a „jegyzőkönyv lezárását jelző »Kmf « kivakarása után ama rendelkezést, hogy az ítélet a felek képviselőinek kézbesíttessék, azzal toldotta meg, hogy a felülvizsgálati határidő az ítélet kézbesítésétől fog számíttatni”. ${ }^{21}$ Mindezt tette úgy, hogy a felek erre irányuló kérelmet nem terjesztettek elő, és ilyen tartalmú határozat nem született. A sommás eljárásról szóló 1893: XVIII. tc. 118-119. \$\$, amelyek ügyviteli eljárási szabályokat is rögzítettek, kimondta, hogy „a felek jelenlétében hozott ítéletnek közlése

per és a korabeli büntető eljárásjog. Jogtörténeti Szemle, (2012), 4. sz. 22-34.; Blutman László: A rejtélyes tiszaeszlári per. Budapest, Osiris, 2017.

20 CSML Szegedi Îtélőtábla Elnöki iratok VII.1. 14. doboz, M.K.

21 CSML Szegedi Îtélőtábla Elnöki iratok VII.1. 14. doboz 1896. S. Sz. 
kihirdetés által történik”. A törvény kizárta, hogy a felülvizsgálati határidőt a kihirdetéstől eltérően más időponttól számítsák. E tényekre alapozva az ügyész a vádiratban úgy fogalmazott, „minthogy szabálytalan cselekmény semmiképpen nem menthető, s minthogy olyan szabálytalanság, a hivatali kötelességnek olyan megszegése forog fenn, mely esetleg más alkalommal a közbizalom megrendülését vonja maga után, »rosszallásban «”22 kérte marasztalni a jegyzőt. A fegyelmi eljárás során a tanúk, sőt az eljáró bírói tanács tagja is megerősítette a vádlott azon állítását, hogy a fellebbezési eljárás végén a tanács elnöke az ítéletnek csak a rendelkező részét hirdette ki, az indokolást nem. A bírói tanács még együtt volt, amikor az alperes ügyvédje azt kérdezte az elnöktől, „miként éljen a felülvizsgálati kérelemmel, ha az indokolást nem ismeri?”. A tanács elnöke azt válaszolta, hogy az ítéletet megkapja írásban. A vádlott a fegyelmi eljárás során azt is elmondta, hogy a törvényszéken az volt a gyakorlat, hogy a tárgyalás jegyzője úgynevezett jegyzetet készített, azt adták át ellenőrzésre a tanács elnökének. Amikor ő azt jóváhagyta, akkor írták le és vitték aláíratni. Ebben az esetben is így gondolta a jegyző, hogy az általa az elnöknek elöterjesztett jegyzőkönyvet - ahol a „Kmf” jelzést kivakarta és beleírta, hogy a felülvizsgálati kérelem előterjesztésének a határideje a kézbesítéstől fog kezdődni - az elnök még kijavítja, de nem ez történt, hanem minden módosítás nélkül aláírta.

A sommás ügyviteli szabályok tiltották, hogy jegyzőkönyvekben „vakarással” bármilyen javítást tegyenek. A vádlott arra a kérdésre, amelyet többször, ismételten feltettek neki - mikor írta bele a jegyzőkönyvbe a vád tárgyává tett mondatot -, mindig azt válaszolta, hogy a jegyzőkönyvet - amelyet úgy vitt be az elnöknek, hogy ő azt átnézi - az elött javította ki, illetve toldotta bele a felülvizsgálatra vonatkozó megjegyzést, mielőtt az elnök aláírta volna. A fegyelmi eljárás során az is bizonyítást nyert, hogy a tanács elnöke az ítéletnek csak a rendelkező részét hirdette ki, sőt ő maga válaszolta az ügyvéd kérdésére, hogy az ítéletet kézbesítik. Ebből a törvényszéki jegyző azt következtethette - miután mindenki hallotta, hogy az elnök mit válaszolt az ügyvédnek -, hogy a felülvizsgálatra vonatkozó határidő módosul. A jegyző nem tagadta, hogy a leírt jegyzőkönyvet módosította, de még az elnök aláírása előtt. Az eljárás során tanúként meghallgatták a tanács elnökét is, aki azt vallotta, „lehetséges, hogy a jegyzőkönyv aláírásakor a kérdéses záradék a jegyzőkönyvbe már be volt vezetve". ${ }^{23}$ Mindezekre tekintettel, a törvényszéki aljegyzőt felmentették a fegyelmi vétség vádja alól. Az indokolásban a fegyelmi bíróság kimondta, hogy a vádlott „a tárgyalási jegyzőkönyvbe a valóságnak meg nem felelő záradékot vezetett be, melyet menthető tévedésnek kellett tekinteni, s ekként cselekménye miatt vétkes kötelezettségszegést nem lehet megállapítani”. ${ }^{24}$

(A feltárt iratok között nem szerepel utalás arra, hogy a bírói tanács elnökét figyelmeztették-e, hiszen azzal, hogy az ítéletnek csak a rendelkező részét hirdette ki, és az indokolást nem, megszegte az ügyviteli szabályokat. Ténylegesen a tanácsvezető bíró követte el a kötelességszegést.)

\footnotetext{
22 CSML Szegedi Ítélőtábla Elnöki iratok VII.1. 14. doboz 1896. S. Sz.

23 CSML Szegedi Îtélőtábla Elnöki iratok VII.1. 14. doboz 1896. S. Sz.

24 CSML Szegedi Îtélőtábla Elnöki iratok VII.1. 14. doboz 1896. S. Sz.
} 


\section{3. „A FELETTES HATÓSÁGNAK TARTOZÓ TISZTELET MEGTAGADÁSA”}

Az eljárási szabályok megsértésének egy sajátos esete fordult elő az egyik törvényszéken. Súlyos testi sértés büntettében folyó eljárás végére értek, de a végtárgyalásról a bírói tanács egyik bírája anélkül távozott déli 12 órakor, hogy erre az elnök engedélyt adott volna. Ez a magatartása a bírónak azt eredményezte, hogy az elnöknek szünetet kellett elrendelni, hiszen egy büntetőeljárásban a bírói tanács minden tagjának az eljárás elejétől a végéig ott kell lennie. A tanács elnöke jelentette az esetet a törvényszék elnökének, aki megtette a szükséges intézkedéseket ahhoz, hogy az ügyészség fegyelmi vétség miatt eljárást indítson. Miután ennek az esetnek az iratai nagyobb részt megmaradtak, a konkrét eset sok más, a bíróságok müködésével kapcsolatos dologra is rávilágít. A fegyelmi eljárás alá vont bíró valójában nem tudta megindokolni, miért hagyta el a tárgyalótermet. Védekezésében arra hivatkozott, hogy szédült, rosszul volt, de ezt a tárgyaláson ott lévők közül senki nem vette észre. Majd azt hozta fel saját védelme érdekében, hogy nagyon meg van terhelve, túl nagy az ügyforgalom, hétvégén is benn kell lennie, és senki sem kötelezheti őt arra, hogy 12 óra után is tárgyaljon. Betegségét orvos szakértő nem támasztotta alá, bár több bírótárs vallotta, hogy a fegyelmi eljárást megelöző időben gyakran panaszkodott szédülésre. Ha az érintett bíró volt az eljáró tanács elnöke, a tárgyalást 12-re vagy befejezte, vagy szünetet rendelt el. Ha más vezette a tárgyalást, akkor többször kérte az érintettet, hogy 12-kor tartsanak szünetet. A fegyelmi eljárás irataiból az is egyértelművé válik, hogy a konkrét esetben a bírói tanácsot vezető bíróval a vádlott nem ápolt jó kapcsolatot, sőt kifejezetten negatív véleményt írt róla. Az eljárás során elismerte, sőt fenntartotta nemcsak a bírótársát, de feletteseit is sértő megjegyzéseit. Ezek közül még az utókor olvasója számára is meglepő az a kijelentése, amelyet a törvényszék elnökére tett, és amit a fegyelmi eljárás során is elismert. „Mióta Méltóságod a [...] törvényszéket vezeti, már több ízben büntető tanácsi vezetőket kinevezett. Egy-két esetet kivéve, ezen kinevezések oly szerencsétlenül ütöttek ki, hogy bátran állíthatom, hogy ők okozták mindazon botrányos állapotokat.” ${ }^{{ }^{25}}$ Ezzel az állításával nemcsak a törvényszék elnökét, de szinte valamennyi bírótársát is megsértette, akik vele együtt büntetö ügyszakba voltak beosztva. Mindezeket figyelembe véve az ügyészség a vádat arra alapozta, hogy „a vádlott az elnöklő bíró tiltakozása ellenére távozott, bírótársa és a törvényszék elnökének megsértésével elkövetett kötelességszegései egy akaratelhatározással eredő és folytatólagos, tehát egységes cselekményt képeznek, a fegyelmi vétség tényálladékát magában foglalja, ezért egyrendü fegyelmi vétségben vétkes" ${ }^{26}$ Súlyosbító körülményként ítélték meg, hogy a vádlott eltávozása a tárgyalóteremből az ott levőkben megütközést keltett, magatartása az igazságszolgáltatás tekintélyét felette érzékenyen csorbította, és fokozta a vádlott vétkességét, hogy magatartásával helyenként a „hivatali hatalommal való visszaélés” vétségének ismérveit is feltünteti. Ez a megállapítás azért fontos, mert a hivatali hatalommal való visszaélés tényállását az 1878: V. tc 480. \$-a

25 CSML Szegedi Ítélőtábla Elnöki iratok VII.1. 14. doboz 1896.

26 CSML Szegedi Îtélőtábla Elnöki iratok VII.1. 14. doboz 1896.; Homoki-Nagy (2017) i. m. 55-57. 
szabályozta. ${ }^{27} \mathrm{Ha}$ ez valóban fennállt, akkor büntetőtörvénybe ütköző magatartása miatt, a bíró ellen rendes bűnvádi eljárást kellett volna indítani. Ez nem történt meg, de a súlyos kötelességszegés miatt a fegyelmi eljárás elindult. A vádiratban kiemelte az ügyész, hogy „a hivatali állás tekintélye, valamint a hivatalos érintkezésnek természetes szabályai megkövetelik azt, miszerint a hatóságot tagjai úgy a hivatalos müködés körében általában, mint különösen egymás hivatali intézkedéseinek megbírálásában a tisztesség követelményeit szem előtt tartsák [...] Éppúgy hivatali kötelessége a bírónak, mint minden köztisztviselőnek, hogy a felügyeleti hatósággal szemben kellő tiszteletet tanúsítson, s nem menti a kötelességszegést sem az egyik sem a másik esetben az, hogy a sértések védelmi nyilatkozat elöterjesztése alkalmából követtettek el."28

A fegyelmi vétség miatt eljárás alá vont bíró nem először hivatkozott arra, hogy bírótársai nem alkalmasak bizonyos ügyek tárgyalására, és éppen ezért őneki kellett sokkal nehezebb és bonyolultabb ügyeket tárgyalni. Túlterhelték, ezért volt rosszul, állította az eljárás során. Ez volt az az állítása, amely miatt a fegyelmi bíróság jelentést kért arról, hogy a törvényszék büntetőbírái mennyi ügyet kaptak, hány büntetőtárgyaláson voltak tanácselnökök, hányban csak tagok, mennyi ügyben kellett ítéletet írni, volt-e ügyhátralékuk. A büntetőtanácsok elég sok ügyet tárgyaltak, de a jelentés szerint a bírák átlagban napi négy órát töltöttek hivatali helyiségükben. Ez a megállapítás az érintett bíróra is igaz volt. Sőt az eljárás tárta fel azt is, hogy több bírótárs az érintett bíró személyisége miatt panaszkodott, de betegségére hivatkozva írásbeli panaszt nem terjesztettek elő. ${ }^{29}$

Ugyancsak a fegyelmi eljárás során váltak ismertté azok az esetek, amikor fegyelmi vétség miatt már korábban is eljárást indítottak a bírók ellen. Miközben társait bírálta, és alkalmatlannak állította őket, aközben egy büntetőügy végtárgyalási jegyzőkönyvét „elfelejtette aláírni”. Más esetben is megszegte az ügyviteli szabályokat, amelyek miatt a törvényszék elnöke többször megintette, és ezt személyi lapjára is rávezették. ${ }^{30}$

A bírót mind az első fokon eljáró fegyelmi tanács, mind a másodfok vétkesnek találta, és nemcsak azt a cselekményt minősítették fegyelmi vétségnek, amiért elhagyta engedély nélkül a tárgyalótermet, hanem azt is, hogy „a felettes hatóságnak tartozó tisztelet megtagadásával, közhivatalban lévő egyén hivatali kötelességét is megszegi; ezért vádlott e tényével is fegyelmi vétséget követett el”. ${ }^{31} \mathrm{Az}$ ítélet indokolásában még azt is kiemelte a másodfokon eljáró fegyelmi bíróság, hogy a vádlott eljárásában „rossz példa rejlik, mert ha követőkre találna, veszélyes helyzetet teremtene”. ${ }^{32}$ A súlyos kötelezettségszegés miatt a bírót vétkesnek, ezért feddésre és 50 forint pénzbüntetésre ítélték. ${ }^{33}$

27 „Hivatali hatalommal való visszaélés vétségét követi el és három hónapig terjedhető fogházzal büntethető azon közhivatalnok, aki hivatali kötelességének teljesítését megtagadja.”

28 CSML Szegedi Ítélötábla Elnöki iratok VII.1. 14. doboz 1896. Sch. F.

29 CSML Szegedi Ítélőtábla Elnöki iratok VII.1. 14. doboz 1896. Sch. F.

30 CSML Szegedi Îtélőtábla Elnöki iratok VII.1. 14. doboz Sch. F.

31 CSML Szegedi Îtélőtábla Elnöki iratok VII.1. 14. doboz Sch. F.

32 CSML Szegedi Îtélőtábla Elnöki iratok VII.1. 14. doboz Sch. F.

33 A konkrét fegyelmi eljárás irataiban olvasható állítások jogossá teszik azt a kérdést, hogy az ítélőtábla elnöke, a törvényszékek és a járásbíróságok kötelező ellenőrzése során kitért-e a büntetőbírák tevékenységére? A másik 


\section{RÁGALMAZÁS GYANÚJA MINT FEGYELMI VÉTSÉG}

A Szekszárdi kir. törvényszék rágalmazás miatt indított büntetőeljárást V. L. ügyvéd ellen, aki az eljárás közben abbahagyta ügyvédi praxisát, és bírói statust pályázott a Szegedi törvényszéknél. Bírói kinevezést nyert, így a rágalmazás miatt megindított büntetőeljárás következtében már mint bíró ellen indították el a fegyelmi eljárást. Az 1869: IV. tc. 6. \$-ának rendelkezése szerint bíróvá csak feddhetetlen jellemü embert lehetett kinevezni. Ezért, amikor a királyi törvényszék elnökének tudomására jutott, hogy büntetőeljárás indult a bíró ellen, szükségszerű volt a fegyelmi eljárás megindításának kezdeményezése a királyi ügyészség elött.

A bíró ellen indított büntetőeljárás alapját az képezte, hogy ügyvédként a paksi járásbíróság előtt, árdrágítás vétsége ${ }^{34}$ miatt indult bűnvádi eljárás során, mint a terhelt védője, a terhelt ellen szóló és a paksi községi elöljáróság által kiállított községi bizonyítvánnyal szemben azt a kijelentést tette: „Ismerem az Ilyen községi bizonyítványok bizonyító erejét, hozzatok más vagy ellenkező tartalmú bizonyítványt!’35 Ezt az ügyvédi állítást az érintett község bírája és jegyzője úgy értelmezte, hogy az ügyvéd olyan tényt állított, amely alkalmas arra, hogy ellenük bünvádi vagy fegyelmi eljárást indítsanak. Miért kellett a községi bírónak és jegyzőnek úgynevezett községi bizonyítványt kiadni? Az árdrágítással megvádolt terhelt eladott egy kazal szalmát 5000 koronáért. A vevő a megállapodás ellenére nem vette át a szalmát, sőt, az eladó ellen pert indított árdrágításra hivatkozva. Állításának alapját az képezte, hogy a község elöljárói kiadtak egy bizonyítványt, amely szerint egy kazal szalma az eladás időpontjában Pakson 4000 korona volt. Eszerint az eladási ár és a község igazolásában meghatározott érték között olyan lényeges különbség volt, amely az árdrágítás vétségének tényállását kimerítette. Az I. világháborút követő gazdasági válság szükségszerüen hozta magával, hogy a hiánycikkek ára megemelkedett. A törvényalkotó igyekezett keretek között tartani a hiánycikkek árának növekedését, és ezzel függött össze az árdrágító magatartások visszaszorítását célzó törvény megszületése is. Esetünkben a terhelt a törvényi tényállás első mondatát valósította meg, ha bizonyítást nyer, hogy a községi bíró és jegyző által kiállított okirat szerint egy kazal szalmáért ténylegesen csak 4000 koronát kérhetett az eladó. A kérdés természetesen az volt, hogy az egy kazal szalma árának meghatározására jogosult hatóság az adásvételt megelőzően ezt 4000 koronában maximálta-e, vagy sem. Az ügyvédi állításból - „hozzatok más vagy ellenkező tartalmú bizonyítványt" - tagadhatatlanul kiolvasható az, hogy lehetne más összeget

kérdés, ami ilyen esetekben elgondolkoztatja a késő kor kutatóját, miképpen tudtak ezt követően együtt dolgozni a bírók? Hiszen a bírókat nem lehetett egyik helyről a másikra áthelyezni, így a fegyelmi eljárás során hozott ítéletben sem merült fel az áthelyezés kérdése, ezért továbbra is együtt kellett müködniük a bíráknak. Vö. Navratil (2014) i. m. 134.

34 „Árdrágító visszaélés vétségét követi el: 1. aki közszükségleti cikkért a törvény értelmében erre jogosult hatóság részéről megszabott vagy megengedett legmagasabb árnál magasabb árt követel, köt ki vagy fogad el, vagy aki közszükségleti cikket nyereséget célzó továbbeladás végett a legmagasabb árnál magasabb áron vásárol.” Az árdrágító visszaélésekről szóló 1920 . évi XV. tc. 1. \$.

35 CSML Szegedi Îtélőtábla Elnöki iratok 8. sz. doboz. 
tartalmazó községi bizonyítványt is beszerezni, adott esetben éppen a terhelt védelmére. Paks község korabeli bírója és jegyzője ezt tekintette magára nézve sértőnek, ${ }^{36}$ hiszen mint a község választott tisztségviselői felelősséggel tartoztak hivatali kötelezettségeik teljesítéséért. Márpedig, ha valaki azt állítja, hogy a bizonyításra alkalmas hivatali iratot valakinek az érdekében adták ki, az bizony megalapozhatta a fegyelmi eljárás megindítását velük szemben. Ezért tekintették az ügyvéd állítását rágalmazásnak, ami viszont az ügyvéd ellen a büntetőeljárás szükségszerü megindítását eredményezte.

A büntetőeljárásban a bíró elismerte állítását, és azzal védekezett, hogy egyrészt a község elöljáróinak nem volt hatásköre arra, hogy a tőzsdén jegyzett árura vonatkozóan az árat megszabják, másrészt az általuk kiállított bizonyítvány közokirat, amely ellen ellenbizonyítást kérhetett. Ezért kérte szakértők meghallgatását az eljáró bíróságtól.

A Szekszárdi kir. törvényszék, az ekkor még ügyvéd V. L.-t rágalmazás vétségében marasztalta, pénzbüntetésre és 400 korona mellékbüntetésre ítélte, amelyet a vádlott büntetlen elöéletére hivatkozva három év próbaidőre felfüggesztett. A törvényszék az ítélet indokolásában kiemelte, hogy „a vádlott a községi bizonyítványra vonatkozó kritikáját megtehette volna olyan formában is, amely a bizonyítványt kiállító elöljárósági tagokat nem sértette volna" ${ }^{37}$

A bíró fellebbezett az ítélet ellen - időközben már a szegedi kir. törvényszék bírája lett - és a jogorvoslati eljárás során a Pécsi Ítélőtábla a szekszárdi törvényszék ítéletét megsemmisítette, és a bírót felmentette a rágalmazás vádja alól. Az ítélőtábla indokolásában részletesen kifejtette, hogy az ügyvéd „a vád tárgyává tett kijelentés az annak megtételekor tárgyalt bünügyben - árdrágítás - a jog célirányos érvényesítésére [...] az ügyfél érdekében történt és szükséges volt [...] mivel a vádlott ellenbizonyítást akart elérni [...] (továbbá) kizárja a rágalmazás vagy becsületsértés megállapítását az ügyfél képviselőjének hatóság előtt folyamatban levő ügyben tárgyalás alkalmával szóval tett nyilatkozata, amennyiben a nyilatkozat az üggyel összefügg és a nyilatkozat az ügyfél érdekében szükséges volt”. ${ }^{38}$

A rágalmazás vádja miatt, az időközben bírói statust elnyert bíró ellen a királyi ügyészség fegyelmi eljárást kezdeményezett. Miután a Pécsi Ítélőtábla megsemmisítette a szekszárdi törvényszék ítéletét, az elsőfokú fegyelmi bíróság 1924. május 20 -án a fegyelmi eljárást mellőzte. A döntés ellen a kir. föügyészség semmisségi panaszt nyújtott be, amelyet a koronaügyész fenntartott. Ezért a fegyelmi ügy a Kúria elé került, ahol a másodfokon eljáró fegyelmi bíróság fenntartva a Pécsi Ítélötáblának az indokolás során kifejtett álláspontját, amely szerint nem minősül rágalmazásnak, ha az ügyvéd az ügyfele érdekében tesz olyan nyilatkozatot, amellyel ellenbizonyítást kíván elérni, a semmisségi panaszt elutasította, és ezzel a bírót a fegyelmi vétség vádja alól is felmentette.

\footnotetext{
36 „Rágalmazás vétségét követi el, aki valakiről más előtt oly tényt állít vagy híresztel, amely valóság esetében az illető ellen bűnvádi vagy fegyelmi eljárás megindításának oka lehet vagy pedig őt közmegvetésnek tenné ki." 1914: LXI. tc. a rágalmazásról és a becsületsértésről 1. $\$$.

37 CSML Szegedi Îtélőtábla Elnöki iratok 8. sz. doboz V. L.

38 CSML Szegedi Ítélötábla Elnöki iratok 8. sz. doboz V. L.
} 
Az adott ügy rámutat arra, hogy büntető törvénybe ütköző magatartást sem ügyvéd, sem bíró nem követhet el. A rágalmazás gyanúja megalapozta a fegyelmi eljárás megindítását. A rendes büntető eljárásban a bíróságnak azt kellett eldöntenie, hogy a rágalmazás megtörtént-e, vagy sem. Ezt a kérdést a Pécsi Ítélőtábla tisztázta, és felmentette a vádlottat, mivel nem valósult meg a rágalmazás tényállása. Ugyanakkor a fegyelmi eljárás során azt is tisztázni kellett, hogyha rágalmazás nem történt, a tárgyalás során elhangzott ügyvédi kijelentés megalapozhatta-e a kötelességszegés miatt megindítható fegyelmi eljárást. Ezt a fegyelmi kérdésben hatáskörrel rendelkező bíróságok tisztázták, hiszen az ügyvéd, ügyvédi kötelességét teljesítve, ellenbizonyítást akart elérni. Ezzel nem követett el olyan magatartást, amely a fegyelmi eljárást megalapozta volna.

\section{A JOGTALAN HASZONSZERZÉS}

Egy járásbírót azért panaszolt be egy ügyvéd, mert egy telekkönyvi ügyben kérvényt szerkesztett, illetve a telekkönyvi irat másolatáért, a hivatalosan megállapított illetéken felül, 3 forintot kért. Az eljárás során arra is fény derült, hogy a járásbíró más esetben is elvállalta, hogy ingatlannal kapcsolatos jogügyletekhez az adott ingatlan telekkönyvi adatait kírja, és a szükséges iratokat elkészíti. Ezekért a cselekményeiért pénzt kért és kapott.

A bírói ügyviteli szabályok tiltották, hogy bírósági hivatalnokok a felek érdekében kérvényeket szerkesszenek, így a bepanaszolt bíró, miután az általa készített fogalmazványok és iratok bizonyítékként a fegyelmi bíróság rendelkezésére álltak, fegyelmi vétséget követett el. Súlyosbította az esetet, hogy pénzt kért és kapott a felektől. A fegyelmi bíróság az 1871: VIII. tc. 20. $\$$ a) pontja alapján többrendbeli fegyelmi vétségben marasztalta a járásbírót, külön-külön rosszallással, és 15 forint pénzbüntetésre ítélte. ${ }^{39}$

Azt nem lehet az iratokból megállapítani, hogy miért fegyelmi vétséget és miért nem hivatali bűntettet állapítottak meg, hiszen bizonyítást nyert, hogy a bíró jogtalan haszonszerzéshez jutott azáltal, hogy a telekkönyvi adatok másolásáért és az elkészített fogalmazványokért pénzt fogadott el; bár tagadhatatlan, hogy a telekkönyvi bíró cselekedete nem merítette ki azoknak a cselekményeknek a törvényi tényállását, amelyeket az 1871: VIII. tc. taxatíve felsorolt hivatali bűntettként. Ezért az állapítható meg, hogy a jogtalan haszonszerzést ebben az esetben olyan súlyos kötelezettségszegésnek ítélték, amely a pénzbüntetés kiszabását alapozta meg.

\section{6. „ZÁRÓRÁN TÚL TERJEDÖ MULATSÁG”}

A fegyelmi vétség tényállását meghatározó törvény $20 . \$$ b) pontja rögzíti azt az esetet, amikor a bíró „botrányos magaviselete” alapozta meg a fegyelmi eljárást.

39 CSML Szegedi Ítélőtábla Elnöki iratok VII.1. Z. A. 
B. Gy. járásbíró becsületsértés miatt jelentette fel a kevermesi községi bírót, mert a községi bíró azt állította róla, hogy „egy kiszállás alkalmával annyira lerészegedett, hogy az árokban fetrengett és ezzel a magatartásával közbotrányt okozott” ${ }^{40} \mathrm{~A}$ vádat a királyi ügyészség ejtette, ezért maga az eljárás megszűnt. Ezt követően viszont az ügyészség fegyelmi eljárást indított a járásbíró ellen arra hivatkozva, hogy a járásbíró magatartását megnyugtatóan nem tisztázták, márpedig „a járásbíróról tett állítások olyan súlyosak, hogy azok valódiságának megállapítása feltétlenül szükséges”. ${ }^{41}$ A bizonyítási eljárás során megállapítást nyert, hogy a járásbíró „kiszállások alkalmával zárórán túl terjedő mulatságokban szokott részt venni”, ${ }^{42}$ ahova a bíróság nagyobb számú ügyek miatt - árverések alkalmával, azt megelőzően ingatlan árbecslése - küldték ki. A mulatozásokon az a zárgondnok is részt vett, akinek müködése ellen a község polgárai többször panasszal fordultak az illetékes bírósághoz. Az is bizonyítást nyert, hogy a bíró ellen is panasszal éltek, és a járás főszolgabírája, mint I. fokú rendőri büntetőbíróság kihágás miatt 20 pengő pénzbüntetésre ítélte a járásbírót. ${ }^{43} \mathrm{Az}$ is bizonyítást nyert, hogy a járásbíró mellé jegyzőkönyvvezetőnek kirendelt telekkönyvvezető egy alkalommal szintén botrányosan viselkedett, amelyről a járásbíró nem értesítette felettesét. A fegyelmi bíróság többrendbeli fegyelmi vétség miatt a bírót „feddéssel” büntette.

\section{MULATOZÁS A KÖZSÉG VENDÉGLÖJÉBEN}

Ugyancsak az 1871: VIII. tc. 20. \$b) pontja alapján állapították meg a fegyelmi vétség elkövetését annál a bírónál, aki 1896. október 15-ről 16-ra virradó éjjel az egyik község vendéglőjében mulatott, majd éjfél után 2 óra tájban ugyanazon vendéglő kávéházában a segédtelekkönyvezetővel, egy kereskedősegéddel és egy kereskedővel kártyázott reggel fél hétig. Ekkor a kártyázásból adódóan $5 \mathrm{ft}$-ot követelt a kereskedősegédtől, aki a követelést vitatta, majd összeverekedtek, és csak a kocsmáros tudta őket szétválasztani. Az eset akkor történt, amikor a község lakosai reggel betértek a kávéházba, és mindezt látták. A bírónak a segédtelekkönyvvezetővel együtt 9 órakor egy ingatlan jogügylettel kapcsolatban meg kellett volna jelennie egy általa meghirdetett szemlén, amelyen mámoros állapota miatt nem jelent meg. A helyszíni szemlén megjelent szakértők, az ügyfelek és képviselőik panaszt emeltek, aminek következtében megindult a fegyelmi eljárás. A bíró magatartását súlyosbította, hogy neki kellett volna felügyelnie a segéd-telekkönyvezető munkáját, amit nem tett meg, és természetesen nem jelentette felettesének, hogy a segéd ittas volt. A fegyelmi

\footnotetext{
CSML Szegedi Ítélőtábla Elnöki iratok 8. doboz B. Gy.

CSML Szegedi Ítélőtábla Elnöki iratok 8. doboz B. Gy.

CSML Szegedi Îtélőtábla Elnöki iratok 8. doboz B. Gy.

3 Az iratok tanúsága szerint a járásbíró az 1879: XL. tc. 74. \$-ába ütköző cselekményt követett el. Ez a szakasz a közrend és a közszemérem elleni kihágásokról szóló tényállást rögzíti. „Azon vendég [...] aki a záróra után a vendéglős kocsmáros, kávéház tulajdonos vagy ezek megbízottjának vagy a hatósági közegnek felhívására el nem távozik, vagy elrejtőzik: huszonöt forintig terjedhető pénzbüntetéssel büntetendő."
} 
bíróság vétkesnek mondta ki a bírót botrányos magaviselete miatt, amely alkalmas volt arra, hogy „a bíró tiszteletre és bizalomra méltatlanná váljon”. Ezért pénzbüntetésben marasztalták. ${ }^{44}$

\section{ELINTÉZETLEN ÜGYEK MIATTI HANYAGSÁG}

A hivatali kötelezettség megszegésének „„öbbszörös” esetével találkozhatunk egy 1929-ben megtörtént esetben. Az egyik járásbíróság vezető bírája azzal a panasszal fordult hivatali feletteseihez - az illetékes törvényszék és az ítélőtábla elnökéhez -, hogy „súlyosabb természetű elintézési késedelmek és egyéb hanyagság miatt felügyeleti vizsgálatot kér a bíró ellen". ${ }^{45}$ A vizsgálat során megállapították, hogy 1930. február 14-én büntetőügyekben 107 db elintézetlen beadványa volt, amiből a legrégebbi 1928. december 26-án érkezett. Néhány ügyben az eljárás már elévült. Ezenkívül a bíró kezén volt $74 \mathrm{db}$ aláiratlan és elintézetlen tárgyalási jegyzőkönyv, a legrégebbi ügyet 1929. augusztus 20-án tárgyalta. $41 \mathrm{db}$ megfellebbezett, és ugyanannyi jogerős írásba nem foglalt ítélet is a bíró asztalán hevert. 1929. szeptember 28-tól 1930. február 11-ig kitűzött, de elnapolt tárgyalások közül 28 ügyben a jegyzőkönyveket nem készítette el. Az 1929. augusztus 28. és 1929. december 21. között kihirdetett ítéletek ellen bejelentett fellebbezések alapján az iratokat 28 ügyben a kir. törvényszékhez nem terjesztette fel. A vezető járásbíró mindezeken túl azt is panaszolta, hogy a bíró, amikor nincs tárgyalása, igen ritkán, vasárnap és hétfőn pedig egyáltalán nem jár be a hivatalba. Bűnvizsgálatok elvégzésével is megbízták, de a sürgős cselekményeket sem végezte el, tárgyalásairól gyakran igazolatlanul távol maradt. Távollétét soha sem tudta igazolni. Végső soron a közvetlen felettes azt kérte, hogy a bepanaszolt bíró „hivatalos müködése közben és magánéletében is oly botrányos magatartást tanúsított, hogy a bírói állás tekintélyének megóvása szempontjából, közérdekből eddigi székhelyéről a lehetö legsürgősebben áthelyeztessék" ${ }^{46} \mathrm{~A}$ felettes hatóság előbb kötelezte a járásbírót, hogy rövid határidőn belül - ez két hónapot jelentett - dolgozza le hátralékát, és „,csekélyebb rendetlenségre és késedelemre" hivatkozva írásbeli hivatalos megintésben részesítette a bírót. Ezt követően a bírót 1930-ban egy másik járásbíróságra áthelyezték.

1933-ban ennek a járásbíróságnak a vezetője is panasszal élt az áthelyezett bíró ellen, mondván: az ítéleteket nem foglalta írásba, a 9 órára kitüzött tárgyalásokon nem jelent meg, távollétét nem igazolta. Ha délben bement a hivatalába, feladatát nem volt képes ellátni. Estéit zugkocsmákban, bírói állásával össze nem férő társaságban töltötte, ahol gyakran leittasodott. Egyik alkalommal „este 9 óra tájban teljesen ittas állapotban nyílt utcán a járdára zuhant, s onnan felkelni nem tudott. Nagymérvü és rendszeres alkohol

44 CSML Szegedi Îtélőtábla Elnöki iratok VII.1. 1896. E. G. személyi adatlapjából megtudható, hogy az esetnek további következményeképpen a bíró kérte, hogy másik járásbírósághoz helyezzék át.

CSML Szegedi Îtélőtábla Elnöki iratok VII.1. 13. doboz L. E.

CSML Szegedi Ítélőtábla Elnöki iratok VII.1. 13. doboz L. E. 
fogyasztás miatt idegrendszere kóros tüneteket mutat s szervezetének ellenállási képessége annyira lecsökkent, hogy csekélyebb mennyiségü alkohol fogyasztása is mámorossá teszi." ${ }^{\prime 7}$

$\mathrm{Az}$ újabb fegyelmi eljárás során a bíró azzal védekezett, hogy a háború alatt katonai szolgálatot teljesített, amiből kilenc hónapot súlyos körülmények között a fronton töltött, és idegei ez idő alatt romlottak meg. ${ }^{48} \mathrm{~A}$ vádakat tagadta. Kérte, tekintsenek el a fegyelmi úton való kényszernyugdíjazástól, mert a Sátoraljaújhelyen élő özvegy édesanyját és két, tanítónői diplomával rendelkező, de állásnélküli nővérét is ő tartja el bírói fizetéséből. Egy bíró kényszernyugdíjazására csak különösen súlyos esetben kerülhetett sor. ${ }^{49}$ Ekkor még eltekintettek a kényszernyugdíjazástól és ezáltal a hivatalvesztés kimondásától.

A fegyelmi eljárás alatt a bíró a hátralékokat feldolgozta. Az ítélőtábla elnöke viszont törvényszéki orvosi vizsgálatot kért annak eldöntésére, hogy a bíró a bírói tiszt viselésére alkalmas vagy alkalmatlan. A bírót a Szegedi Egyetem ideggyógyászati osztályán kezelték négy hónapig. ${ }^{50}$

Egy rövid ideig a bíró megpróbálta hivatali teendőit ellátni, de néhány hét után kezdődött minden elölről. Az is kiderült, hogy nemcsak zugkocsmákba jár, hanem rendszeresen látogatta a bordélyházat. Éjszakai élete miatt reggel nem tudott felkelni, így bírói hivatását sem tudta teljesíteni, „hivatali és magánéletében olyan magatartást tanúsított, ami az ítélőbíró tisztes állásával össze nem egyeztethető”. Miután a bíró mulasztásai és a panaszokban jelzett magatartások mindig újból kezdődtek, sőt egyre rosszabb lett, 1933-ban már nem tudtak eltekinteni felettesei a legsúlyosabb döntéstöl. Az 1912: LXV. tc. rendelkezése szerint a bírót saját kérésére nyugdíjazták.

\section{A POLITIKAI ÖSSZEFÉRHETETLENSÉG}

A bírói hatalomról szóló 1869: IV. tc. egyik igen fontos rendelkezése volt a bírói függetlenséggel összefüggésben az összeférhetetlenség kérdésének a szabályozása. E szabályok között rendelkezett a jogalkotó arról, hogy „a bíró nem lehet tagja valamely politikai vagy munkás-egyletnek, illetőleg gyülekezetnek, nem vehet részt azok gyüléseiben; nem folyhat be sem közvetve, sem közvetlenül azok müködéseibe, s nem járulhat az ily egylet vagy gyülekezet határozatához vagy kérvényéhez". ${ }^{51}$ A társadalmi, gazdasági és anyagi értelemben vett függetlenség kérdését a politikai életre is kiterjesztette a jogalkotó, és bár a törvény

47 CSML Szegedi Îtélőtábla Elnöki iratok VII.1. 13. doboz L. E.

48 CSML Szegedi Ítélőtábla Elnöki iratok VII.1. 13. doboz L. E. személyi lapjába is bejegyezték, hogy 1914. december 14-én vonult be, de 1915. január 6-án elbocsátották, majd 1915. június 17-én ismét bevonult, 9 hónapos frontszolgálatot teljesített, és ott szerzett betegsége miatt 1918. november 30-a és 1919. augusztus 4-e között kórházban volt.

49 Patyi Zsófia: A bírák fegyelmi felelősségének bő évszázados alakulása I. (1868-1954). Acta Juridica et Politica: Forum Publicationes Doctorandorum Juridicorum, 6. (2016), 147-164. 155.

50 CSML Szegedi Ítélőtábla Elnöki iratok VII.1. 13. doboz Miskolczy Dezső jelentése.

51 1869. évi IV. tc. $11 . \S$. 
keletkezésének idején a politikai pártok, érdekképviseleti szervek jóval jelentéktelenebb szerepet kaptak, mint a 19-20. század fordulóján, mégis biztosítani kívánták az igazságszolgáltatás politikai értelemben vett érinthetetlenségét.

Az I. világháborút követően azonban több fegyelmi eljárás is indult, amelyek hátterében az 1918 és 1920 közötti időszak történelmi eseményei álltak. ${ }^{52} 1918$ őszén, amikor a világháború elvesztését Tisza István miniszterelnök bejelentette, majd november 13-án IV. Károly kiadta eckartsaui nyilatkozatát, amelyben ténylegesen lemondott a közügyek viteléről, a Budapesten kirobbant zavargások hatására 1918. október 25-én megalakult a Magyar Nemzeti Tanács és Tisza megölését követően Károlyi Mihály lett az ország miniszterelnöke. Ténylegesen olyan helyzet alakult ki az országban, amely lehetetlenné tette a helyi közigazgatási szervek működését. Vidéken a közrend biztosítása érdekében, november elején megalakították a helyi nemzeti tanácsokat, amelyek tagjait az adott község, város megbecsült polgárai közül választotta a közösség. Ez történt többek között Szarvason is, ahol 1918. november 3-án választották meg a szarvasi nemzeti tanács tagjait. Ennek elnöke dr. Tóth Pál lett, aki „az elnöki tisztet népszerűségének köszönte, melyet a háború alatt szerzett. Mint fö- majd ezredorvos, barátságos és szelíd bánásmódjával megszerettette magát a Neuhaus-ban előtte megfordult sok ezer katonával s kedves ember lett azok szarvasi hozzátartozói elött. [...] Az elnökséget elvállalta, állítása szerint azért, hogy a forradalom zavaros világában a rend helyreállításán hatékonyabban munkálkodhasson." ${ }^{33}$ A Szarvasi Nemzeti Tanács tagjaivá választották „Nagy Sándor posta és táv. felügyelöt, Áts Nagy Ferenc vezető járásbírót, dr. Haviár Gyula kir. közjegyzőt, Pataki János tanítót, Dr. Kész Ármin ügyvédet, Klein János, Klucsjár Mihály és Ambrus Mátyás iparosokat”. ${ }^{54}$

1920-ban a Gyulai törvényszék elnöke fegyelmi eljárást kezdeményezett Áts Nagy Ferenc járásbíró ellen, amely eljárást az a tény alapozott meg, hogy a bíró „tagja, sőt alelnöke volt a Károlyi féle forradalom alatt a szarvasi nemzeti tanácsnak [...] annak november 16-án tartott ülésén a nemzeti tanács a megyei nemzeti tanács gyülésére küldötte ki, mint egyik képviselőjét, amelyet elfogadott és a megyei központi nemzeti tanács alakuló ülésén részt vett”. ${ }^{55} \mathrm{~A}$ bíró elismerte ezt, és e tény alapján 1921-ben az ügyészség vádat emelt ellene.

Mielőtt az iratokat részletesebben ismertetném - 100 év távlatából nézve az eseményeket -, könnyebben mondhatjuk azt, hogy az 1918 novemberében országszerte felállított nemzeti tanácsok valójában politikai testületek voltak még akkor is, ha az országban kialakult helyzetre tekintettel az abban részt vevők elhitték - legalább is kezdetben -, hogy a meg nem szüntetett, de ténylegesen nem megfelelően működő közigazgatási szervek helyett, a közrend és a közbiztonság biztosítása érdekében a helyi közösség életének működtetését kellett megvalósítaniuk. „Az államszervezet központi és helyi szerveinek egy része továbbra is megmaradt változatlan, vagy részben módosított szervezettel, feladat- és hatáskörrel, más részüket új szervek váltották fel, s mindezek mellett a forradalom

Lásd ehhez: Navratil (2014) i. m. 134-135.

Neumann Jenő: Szarvas nagyközség története; az új Szarvas alapitásának 200 éves jubileuma. Szarvas, 1922.

Uo. 101-113.

CSML Szegedi Ítélőtábla Elnöki iratok 13. sz. doboz ATS. 
során jelentkezett új állami feladatok és funkciók ellátására új forradalmi szervek is alakultak. [...] A károlyi-rendszer ezt [...] az igazgatási szervezetet az országos gyakorlatnak megfelelően [...] igyekezett eleinte érintetlenül hagyni. [...] Az 1918. október 25-én létrehozott Magyar Nemzeti Tanács mintájára november elején sorra alakultak a helyi nemzeti tanácsok, [...] és ezek mellett alakultak meg a munkások, parasztok, katonák tanácsai, amelyek igyekeztek rendet teremteni a közellátásban." ${ }^{56}$

Az ügyész a vádiratban a vádat az 1871: VIII. tc. 20 . $\$$ a) és b) pontjára alapította. Állítása szerint a járásbíró hivatali kötelességét vétkesen megszegte, és botrányos magaviselete miatt méltatlanná vált a bizalomra, hiszen egy olyan politikai szervezet tevékenységében vett részt, amely egyrészt politikai okokból müködött, ez összeférhetetlen volt a bírói hivatással, megszegte az 1869: IV. tc. 11. $\$$ - t, amely a politikai összeférhetetlenségről szólt. Másrészt a Károlyi-féle kormány tevékenysége, majd az azt követő Tanácsköztársaság eseményei méltatlanná tettek mindenkit, akik ezekben az eseményekben bármilyen szerepet játszottak. A vádiratban az ügyész részletesen kitért arra, hogy a járásbíró a nemzeti tanács ülésein oly értelmű indítványt tett, „hogy a nemzeti tanács szólítsa fel a szarvasi képviselö testületet, hogy [...] mondjon le, mert a nemzeti tanács vele, mint testülettel szemben bizalmatlansággal viseltetik, a nov. 16-iki ülésen a néphangulatra hivatkozva azt indítványozta, hogy az akkori népkormány belügyminiszteréhez távirati megkeresés intéztessék, hogy a járási főszolgabíró, a községi jegyzők, községi elöljárók és képviselőtestület eltávolítása és helyettesítése iránt 8 napon belül feltétlenül intézkedjék, mert a »Nemzeti Tanács« tovább felelősséget nem vállal, s ezen idő letelte után megbízatását a nép kezébe visszaadja, magáról minden felelősséget elhárít" ${ }^{57}$

A vád alá helyezett járásbíró azzal védekezett, hogy a község lakosai megbíztak benne, és ezért keresték meg azzal a felkéréssel, hogy vegyen részt a helyi nemzeti tanács munkájában. Mielőtt ezt elvállalta, tájékozódott, és megállapította, hogy a gyulai törvényszék több bírája is tagja lett a helyi nemzeti tanácsoknak: „tudomása szerint ez ellen az akkori igazságügyminiszternek sem volt ellenvetése, s felügyeleti hatóságai székhelyein Gyulán és Nagyváradon is beléptek egyes bírák az ottani Nemzeti Tanácsba". ${ }^{58}$ Legfőképpen azért vállalta el ezt a feladatot, és vett részt tevőlegesen is ennek munkájában, mert a helyi közigazgatási szervek nem müködtek. „A Károlyi féle forradalom kitörését követő általános felfordulásban Szarvason a fejüket vesztett, részben állásukat ott hagyott, s különösen a háború utolsó évében már minden téren visszatetszést és felháborodást keltő módon működött közigazgatási szervek és közjogi képviselő testület nem lévén képesek a rendet fenntartani és a polgárok személyét és vagyonát a harctérről visszaözönlő elkeseredett katonák és azok hozzátartozói részéről fenyegető veszélyekkel szemben megoltalmazni." ${ }^{9}$ A világháborúban részt vett katonákat hazaengedték, azoknak nem volt munkája, nem volt

\footnotetext{
56 Buzás József: Székesfehérvár és Fejér vármegye közigazgatása az 1918-1919. évi polgári demokratikus forradalom idején. In Kovács Kálmán (szerk.): Jogtudományi Értekezések 2. Budapest, ELTE, 1971. 5-8.

CSML Szegedi Îtélőtábla Elnöki iratok 13. sz. doboz Áts.

CSML Szegedi Îtélőtábla Elnöki iratok 13. sz. doboz Áts.

CSML Szegedi Îtélőtábla Elnöki iratok 13. sz. doboz Áts.
} 
megfelelő az élelmiszer-ellátás, ezért a zavargásoktól félve, alapvető feladatuknak tartották, hogy a községben a rendet fenn tudják tartani. Ezért javasolta a nemzeti tanács ülésén, hogy az elnök kérje meg a helyi önkormányzatot, oszlassa fel magát, mert így új választásokra kerülhet sor, amelyek révén legitim közigazgatási testület müködhet. Ugyanakkor, amikor érzékelte, hogy a nemzeti tanácson belül nem a békés közigazgatási feladatok megszervezésére helyezik a hangsúlyt, december 11-én lemondott tagságáról. Többet nem vett részt semmilyen ülésen, a politikai élettől távol tartotta magát.

A járásbírót mind az elsőfokú fegyelmi bíróság, mind pedig a Kúria fegyelmi tanácsa, amely az ügyész fellebbezése folytán tárgyalta az ügyet, felmentette. A fegyelmi vétség alól felmentő ítélet indokolásából érdemes részletesen idézni a bíróság álláspontját: „A Nemzeti Tanács, mint a forradalom által proklamált népköztársaság egyik szerve, $s$ amely az állam, megye, város vagy járás közigazgatási ügyeivel a gyakorlatban foglalkozott, politikai természetű gyülekezetnek lévén tekintendő, s a vádlott abban az időben is érvényben volt 1869. évi IV. tc. 11. \$-ának tiltó rendelkezéséhez képest a Nemzeti Tanácsnak tagja nem lehetett volna, mégis az alább kifejtettek szerint úgy találta, hogy a vádlott a jelen kivételes esetben a Szarvasi Nemzeti Tanácsban való közreműködésével nem követett el fegyelmi vétséget megállapító hivatali kötelességszegést s magatartása sem vehető olyannak, amilyent az idézett 1871: VIII. 20. \$ pontjai feltételeznek. Köztudomású ugyanis, hogy a forradalom kitörése után, különösen a harctereken felbomlott hadsereg hazaözönlött katonái főleg a vidéken a személyi és vagyonbiztonságot mennyire veszélyeztették, valamint az is, hogy a, bár nem alkotmányos úton, hanem a forradalom hatása alatt létesült, s magát korlátlan hatáskörrel felruházott Nemzeti Tanács a lakosság személyi és vagyonbiztonsága feletti védelemre is vállalkozott. A lakosság az ő védelme alá helyezte javait és értékeit. A vádlott tehát ilyen rendkívüli körülmények között, [...] azért lépett a közóhajnak megfelelően a kétségtelenül politikai gyülekezetet képező nemzeti tanácsba, s vett részt ennek ülésein s tett a helyzetnek megfelelő indítványokat, hogy állása tekintélyének súlyával is a lakosság biztonságának és nyugalmának a megvédését szolgálja az akkori kivételes, jogrend ellenes és közveszélyes viszonyokra tekintettel. Tehát mintegy erkölcsi kényszer hatása alatt elkövetettnek tekintendő cselekménye annál is inkább nélkülözi a fegyelmi vétség tényálladékát, mert a vádlott meg nem cáfolt védekezése szerint mihelyt a közrend és közbátorság megfelelő mértékben biztosítottnak jelentkezett, még 1918. évi december hó 11-dikén leköszönt abbeli tisztségéröl s nem vett többé részt a Nemzeti Tanács ülésein, [...] vádlott nem hatalmi vágyból vállalta el eme tisztséget, amelyet a vádirat a fegyelmi vétség alapjául tekintett."60

A másodfokú fegyelmi bíróság elfogadva az elsőfokú fegyelmi bíróság ítéletét és annak indokolását, megerősítette, hogy a járásbíró hivatali kötelességét nem szegte meg vétkesen, hiszen a bíró, aki a helyi közéletben szereplő egyén választás útján nyerte el a tisztséget, amelyet közérdekből, a személyi és vagyoni megmentése miatt vállalt el. ${ }^{61}$

60 CSML Szegedi Îtélótábla elnöki iratok 13. sz. doboz Áts.

${ }_{61}$ CSML Szegedi Ítélőtábla elnöki iratok 13. sz. doboz Áts. 
A levéltár által megőrzött iratokat ismerve meggyőződéssel állítom, hogy a konkrét esetben a felmentő ítéletet ténylegesen az alapozta meg, hogy a járásbíró már 1918 december elején lemondott a nemzeti tanácsban viselt tagságáról, amikor világossá vált számára, hogy a politikai események nem teszik lehetővé, hogy helyi szinten függetleníteni tudják magukat az országos politikától.

\section{POLITIKAI SZEREPVÁLLALÁS 1919-BEN}

Egészen másként ítélték meg annak a bírónak a tevékenységét, aki 1919-ben „a szovjet 21-es végrehajtó bizottságban kifejtett ténykedése és a szellemi munkások szakszervezetének a szegedi igazságügyi vezetők kicserélésének szükségességét kimondó határozatának meghozatala körüli müködése és tevékenysége miatt, valamint a »Proletár« c. lapban közzétett nyilatkozatai miatt” vontak fegyelmi eljárás alá már 1919 novemberében. P. A.-t és társait az 1871: VIII. tc. 62 . $\$$ b) pontja értelmében hivatali állásából felfüggesztették, ${ }^{62}$ a vezetői állások betöltése körül kifejtett tevékenységük és a bírói állással össze nem egyeztethető magatartásuk miatt.

Az érintett törvényszék bírái, ügyészei és a jegyzők 1919. május 9-én testületileg kimondták, hogy az érintett bíróval és társaival a hivatali és a társadalmi érintkezést megszakítják. A városban működő Kaszinó választmánya „a hazafiatlan magatartást tanúsított tagok ellen igazolási eljárást indított, ennek végrehajtására bizottságot küldött ki, de a kompromittáltak nem merték magukat a becsületbíróságnak alávetni”. Az érintett bíró 1919. szeptember 13-án lemondott kaszinói tagságáról. ${ }^{63}$

Az elsőfokú fegyelmi bíróság P. A.-t, 1919-ben tanúsított magatartása miatt - különösen a törvényszék bíráinak és elnökének áthelyezésére vonatkozó megjegyzései következtében - a fegyelmi eljárás megindításának időpontjától kezdve hivatalából felfüggesztette, majd ítéletében hivatalvesztésre ítélték. Az ítélet ellen az érintett fellebbezéssel, majd pedig 1926-ban perújítással élt, amelyet a Kúria elutasított. A perújítási kérelemhez csatolt bizonyítékokból, illetve a perújítási kérelmet elutasító végzés indokolásából válik egyértelművé, hogy a törvényszéki bíró arra hivatkozott, hogy „elme- és idegállapota az elítélés alapjául szolgáló cselekmények elkövetése idején olyan volt, hogy fegyelmi úton akkor sem lett volna felelősségre vonható, ha azokat a cselekményeket, illetve nyilatkozatokat, melyek az alapperben terhére rovattak tényleg elkövette, illetve megtette volna” ${ }^{64}$ A vádlott védekezése egyértelmüen beszámíthatatlanságra utal, amit orvosi szakértői véleményekkel kívánt alátámasztani. E vélemények szerint „a vádlott a forradalmi események befolyása folytán sérülékeny, kóros reakciókra alkatánál fogva hajlamos idegrendszere

\footnotetext{
62 „A fegyelmi bíróság hivatalától felfüggeszti a vádlottat: b) ha a felfüggesztés a feljelentett fegyelmi vétség súlyos voltánál vagy természeténél fogva szükségesnek mutatkozik.” 1871. évi VIII. tc. 62. \$ b) pontja.

63 Czímer Károly: A Szeged-belvárosi Kaszinó százéves története (1829-1929). Szeged, Szeged-belvárosi Kaszinó, 1929.

64 CSML Szegedi Îtélőtábla Elnöki iratok 8. doboz P.A.
} 
következtében 1918. év őszén és 1919. év első felében kétségtelenül annyira súlyos endogén nervositasban szenvedett, hogy tetteit, szavait kellően megfontolni, azok következményeit objektíve mérlegelni betegsége folytán képes nem lehetett" ${ }^{65} \mathrm{~A}$ Kúria ítéletében leszögezte, hogy a perújítás alapját képező orvosi bizonyítvány „hét-nyolc évre visszamenőleg csupán következtetéseket magában foglaló orvosi bizonyítvány [...] nem állapítja meg, hogy a vádlott elmeállapota a kérdéses időben meg lett volna zavarva és emiatt akaratának szabad elhatározási képességével nem bírt”. ${ }^{6}$ A vádlott nagyfokú idegessége nem alapozza meg azt, hogy „a törvényszéki bíró fegyelmileg nem lenne vétkes” ${ }^{\circ 7}$ Ezért a hivatalvesztést kimondó ítélet hatályát fenntartotta. Ugyanakkor megerösítette az elsőfokú itélet azon rendelkezését, hogy éppen az orvosilag igazolt ideggyengeség olyan enyhítő körülményt jelentett a törvényszéki bíró esetében, amelynek figyelembevételével a hivatalban eltöltött idő arányában nyugdíjban részesítették. „Miután ezt az idegességet, mint enyhítő körülményt az alapítéletek teljes mértékben értékelték már akkor, midőn vádlott igen súlyos természetű magatartásának elbírálásánál nyugdíjigényét az 1912:VII. tc. 8. §-a alapján a hivatalvesztés kimondása dacára fenntartották.”68

Ha a két esetet összehasonlítjuk, megállapítható, hogy az 1918. novemberi eseményekben részt vett bíró és az 1919 tavaszán történtek hatására tett bírói kijelentések egészen más megítélés alá estek. Az első esetben bár az összeférhetetlenséget megállapították, a fegyelmi vétség alapját képező vétkes magatartást nem, míg a második esetben a bíró kijelentéseit, amelyek még sajtóban is megjelentek, olyan mérvü vétségnek tekintették, amely a hivatalvesztést megalapozta, ugyanakkor a nyugdíjjogosultságot megítélték számára.

\section{AZ IRODAIGAZGATÓ KÖTELESSÉGE}

Ugyancsak 1919-ben elkövetett hivatali kötelesség megszegése miatt emeltek vádat a törvényszéki iroda főigazgatója ellen. A vád szerint „a szociáldemokrata pártvezetőség határozata folytán a sztrájkolni készülő igazságügyi tisztviselőket és altiszteket, ahelyett, hogy a sztrájkban való részvételtől eltiltotta volna azt mondta: aki akar dolgozik, aki akar

\footnotetext{
CSML Szegedi Îtélőtábla Elnöki iratok 8. doboz P. A.

CSML Szegedi Ítélőtábla Elnöki iratok 8. doboz P. A.

CSML Szegedi Ítélőtábla Elnöki iratok 8. doboz P. A.

CSML Szegedi Ítélőtábla Elnöki iratok 8. doboz P. A.; az 1912: VII. tc. 8. \$-a kimondta: „Az 1871:VII. tc. 26. \$-a a következő bekezdéssel egészíttetik ki: A fegyelmi bíróság hivatalvesztést megállapító határozatában különös méltánylást érdemlő okból kimondhatja, hogy a hivatalvesztés a nyugdíjtörvényben meghatározott ellátási igény tekintetében a hivatalvesztésre ítéltre és hozzátartozóira, avagy csupán hozzátartozóira nem jár azzal a következménnyel, a melyet a törvény a szolgálat kötelékéből büntetéskép történt elbocsátáshoz füz. Ebben az esetben az ellátási igény a jogosultat úgy illeti meg, mintha a hivatalvesztésre ítélt a szolgálat kötelékéből végleges szolgálatképtelenség alapján vált volna meg." Ezen törvényi rendelkezés alapján a hivatalvesztést kimondó elsőfokú ítélet „a felfüggesztett állapotban töltött 2 évi és 1 hónapi 2 napi szolgálati idő figyelmen kívül hagyásával - 19 évre terjedő beszámítható és az idézett tc. 11. és $20 \$ \$$ szerint 21 év 8 hónapnak ill. 22 évnek számítandó szolgálata után utolsó beszámítható javadalmazása évi összegének 64 \%-ával felérő nyugdíjat [...] állapított meg”. Ezt tartotta hatályban a perújítási kérelmet elutasító kúriai végzés.
} 
sztrájkol”. Másrészt az irodaigazgató az igazságügyi szakszervezet vezetőségének döntése alapján átiratot fogalmazott meg a bírák, ügyészek és jegyzők szakszervezetéhez, amely átiratban a bírák és ügyészek által elkövetett sérelem miatt nyilvános megkövetést követelt. „E cselekményével a vádlott oly botrányos magaviseletet tanúsított, hogy tiszteletre és bizalomra méltatlanná vált." ${ }^{\prime 9}$

A szociáldemokrata párt a közalkalmazottakra is kiterjedő általános sztrájkot hirdetett 1919. június 15-én, a sztrájk betartását az úgynevezett bizalmi férfiak ellenőrizték, az igazságügyi kezelő tisztviselők bizalmi férfija az irodaigazgató volt. A sztrájk napján a díjnokok egy része nem ment be a hivatalba, és amikor egyesek megkérdezték tőle, hogy mit tegyenek, azt a kijelentést tette, hogy köztisztviselőt az esküje köti, annak sztrájkolnia nem szabad, és felolvasta a büntetőtörvény rendelkezéseit a hivatali kötelesség megszegéséről. A vádlott ugyanakkor írásban jelentette a törvényszék elnökének, hogy a díjnokok egy része a sztrájk miatt nem jött be a hivatalba. A következő napon azonban már mindenki dolgozott. Ez alól a vádpont alól a fegyelmi bíróság felmentette, mivel „a vádlott semmilyen kötelességszegést nem követett el, sztrájkra bátorító kijelentést nem tett, figyelmeztetésen és a felsőbb vezetésnek tett jelentésen kívül más kötelessége nem volt”. ${ }^{70}$

\section{ALKALMATLANSÁG MIATT KÉNYSZERNYUGDÍJAZÁS}

A fent ismertetett esetek elég jól tükrözik, mikor állapítottak meg a fegyelmi bíróságok olyan súlyos kötelezettségszegést, amely a fegyelmi vétség tényállását megalapozta. Utolsó esetként egy olyan történetet ismertetek, amely ugyanakkor arra is rávilágít, hogy bár a hivatali felettesek igyekeztek a bírákat még fegyelmi vétség elkövetése esetén is menteni, végső soron jobb lett volna, ha időben meghozzák azt a döntést, amely a bíró hivatalának elvesztéséhez vezethetett.

Az egyik járásbíróság vezetője még 1916-ban azzal a panasszal fordult hivatali feletteséhez, hogy alkalmatlanság miatt az egyik beosztott járásbírót hivatalából mentsék fel, végső esetben indítsák el az úgynevezett kényszernyugdíjazási eljárást. A járásbíróság elnökének állítása szerint a bepanaszolt bíró nem tudja a tárgyalásokat vezetni, nem tud fegyelmet tartani. „A tárgyalásokon mindenki beszél csak a bíró nem.” Nem tudja eldönteni melyik fél indítványát fogadja el. „Az a benyomásom, hogy annak a félnek indítványát fogadja el, aki hangosabban beszél.” Nem hozott határozatot. Összegezve a járásbíró ellen szóló érveket, a bepanaszolt közvetlen hivatali fönöke azt állította, hogy „a járásbíró állását betölteni képtelen, helyzete tarthatatlan, nem engedhető meg, hogy tudatlanságával a bíróság tekintélyét továbbra is sértse" ${ }^{71} \mathrm{~A}$ fegyelmi vétség megállapításának ez volt az elsődleges szempontja, amely a bírói függetlenség kérdésével is összefüggött. Nem lehet a bíróság tekintélyét, méltóságát semmilyen körülmények között megsérteni.

\footnotetext{
CSML Szegedi Ítélőtábla Elnöki iratok VII.1. 13. doboz irodaigazgató. CSML Szegedi Îtélőtábla Elnöki iratok VII.1. 13. doboz irodaigazgató.

CSML Szegedi Ítélőtábla Elnöki iratok 17. doboz MK járásbíró.
} 
Az eset megítélését nehezíti, hogy az I. világháború alatt a bírák egy jelentős része is katonai szolgálatot, ezen belül gyakran frontszolgálatot teljesített, ezért az ügyek vitelére nem volt elegendő bíró. Ugyanennek a járásbíróságnak a vezetője kérte feletteseitől, hogy helyezzenek oda kisegítő bírót meghatározott időre, mert gyakorlatilag egyedül viszi az ügyeket. A járásbíróság vezetője mindezek mellett engedélyt kért arra, hogy a telekkönyvi betétszerkesztőnek kinevezett bírót a vétségek és kihágások ügyszak vitelével bízza meg, és ezzel egyidejűleg a bepanaszolt bírót bízza meg az öröklési ügyek, valamint a bírói végrehajtást igénylő ügyek elvégzésével. Az engedélyt erre a cserére megkapta, de a helyzet nem változott. A panaszlott továbbra is lassú volt, nem hozta meg időben a döntéseket, ha meghozta, akkor nem foglalta írásba. Mindennek azt lett a következménye, hogy a fegyelmi eljárás megindítása mellett úgynevezett alkalmassági „vizsgának” is alávetették az érintettet, sőt, a kényszernyugdíjazás miatt elmeorvosi vizsgálatot is elrendeltek. Ez utóbbira azért volt szükség, mert a kinevezett bírókat idő előtt csak akkor lehetett nyugdíjaztatni, „ha testi vagy elmebeli fogyatkozás miatt hivatalos kötelességének teljesítésére véglegesen vagy legalább tartósan képtelenné válik" ${ }^{72}$

A fegyelmi eljárásra 1921 márciusában került sor. A tárgyalási jegyzőkönyv adataiból megállapítható, hogy a vádlottat hasonló kötelességszegések miatt, fegyelmi eljárás keretei között előbb írásban megintették, majd az 1912: VII. tc. rendelkezése alapján egy másik járásbírósághoz hivatalból áthelyezték. Az új helyen hasonló kötelességszegéseket követett el, amelyek eredményeképpen újabb fegyelmi eljárások lefolytatását követően előbb „rosszallásra,” majd még egy fegyelmi eljárás végén „feddésre” büntették. A bepanaszolt bíró újból és újból ígéretet tett arra, hogy megjavul, de ez soha sem következett be. Ennek lett a következménye, hogy 1920-ban a járásbíróság vezetője a bíró alkalmatlanság miatti kényszernyugdíjazását kérte. A fennmaradt iratok között megtalálható a törvényszéki orvos véleménye. Ebben az orvos leírta, hogy az érintett bíró „idegrendszerében súlyos fokú elváltozásokat találtam. [...] figyelmét alig bírtam a beszédtémánál tartani. E közben a gyors kifáradás, a szellemi müveletek vontatottsága volt érzékelhető, könnyen elérzékenyül, majd ingerlékeny lesz, fejfájásról, fejnyomásról panaszkodik. Beszéd közben minden átmenet nélkül más tárgyra tér. [...] A feltett kérdéseket többször ismételni kell. Gondolatainak kifejezésére nem találja meg a kellő szavakat [...] megállapítható, hogy a járásbíró úr igen súlyos idegbetegségben szenved [...] összességében a paralysis progressiva kezdeti szaka mutatkozik.” Mindezek után az orvos még azt a megállapítást is tette, hogy ez a betegség idősebb korban visszafordíthatatlan, és tekintettel arra, hogy a vizsgált beteg már 52 éves „az ő jelenlegi munkaképtelensége véglegesnek és állandónak véleményezhetö" ${ }^{73}$ Ugyanakkor egy másik orvos szakértő a betegség tüneteit nem állapította meg, sőt a bírót „teljesen épelméjünek mondta és csak korlátolt szellemi képességü egyénnek találja, akinek szellemi fogyatékosságai még a fiziológiai határok közt mozognak" ${ }^{74} \mathrm{~A}$ vádlott a rá terhelő orvosi vélemény alaposságát megfellebbezte - miután tagadta, hogy beteg lenne -,

1912: VII. tc. 10. $\$$.

CSML Szegedi Îtélőtábla Elnöki iratok 17. doboz 1920. június 26-án kiadott törvényszéki orvos véleménye.

CSML Szegedi Ítélőtábla Elnöki iratok 17. doboz orvosi tanács 3. 
a fegyelmi bíróság két eltérő orvosi véleményre nem támaszkodhatott, ezért a fegyelmi bíróság az igazságügyi orvosi tanácstól újabb véleményt kért. Az igazságügyi orvosi tanács, mivel a vádlott nem jelent meg a megadott időben a személyes vizsgálaton, úgy adott ki orvosi véleményt, hogy a két korábbi szakvélemény tartalmát, valamint a rendelkezésére álló egyéb nyilatkozatokat, amelyek a vádlott személyiségére, viselkedésére vonatkoztak, hasonlította össze. Az orvosi tanács a két szakértő véleményét egybevetve arra a megállapításra jutott, hogy az egyik szakvéleményben leírt elmebaj bizonyos fokára utaló jelek nem valósak, mert ha igen, akkor az eljárás alá vont bíró „már a laikus előtt is elmebajosnak tűnt volna”. ${ }^{75} \mathrm{~A}$ fegyelmi eljárás alá vont bíró által vezetett tárgyalásokon mind a peres feleknek, mind a jelen lévő ügyvédeknek fel kellett volna tünnie. Az egyik, tanúként meghallgatott bírótárs is azt nyilatkozta, hogy „a vádlott nagyon szorgalmasan dolgozik, ott ahol felekkel nem kell tárgyalni el tudja végezni teendőit és a hagyatéki ügyeket most elég jól intézi” ${ }^{76} \mathrm{Az}$ eljárás során kiküldött vizsgálóbíró is arra a megállapításra jutott, hogy a bíró „testileg és lelkileg teljesen ép, az orvosi jelentésben leírt betegségnek nyoma sem észlelhető rajta" ${ }^{77}$

Az orvosi tanács jelentésében arra is kitért, hogy a bíró terhére rótt kötelességszegéseket már sok évvel korábban is elkövette, amiért feddésben, dorgálásban részesült. Végső következtetésként megállapították, hogy a bíró „veleszületett szellemi képességei nem olyanok, hogy hivatásos ügykörének bármely ágában egyformán kellőképpen tudjon megfelelni, hanem csak egyszerübb feladatoknak tud eleget tenni" ${ }^{78}$

Az egyik tanú, aki a büntető ügyszakot átvette az érintett bírótól, vallomásában azt állította, hogy tapasztalta, miszerint a bíró néhány ítéletét a Kúria megsemmisítette, ezeket a tanúnak át kellett néznie, és ekkor tapasztalta, hogy „valószínűleg sok dolga volt az ítélkezésnél, ezért a befejezésen könnyen túl akart esni”, nem fogalmazott kellő körültekintéssel. ${ }^{79}$ Egy másik tanú mint ügyvéd vallomásában kifejtette, hogy a bepanaszolt bíró „az ügyek elemzését rendkívüli nagy szorgalommal és jó akarattal végzi, azonban az ítélkezésnél nincs meg benne az a határozottság és képesség, amely az ügyek helyes megítéléséhez szükséges [...] a tárgyalás rendjét fönntartani nem tudta, túlságos befolyást engedett a felek képviselőinek, úgy hogy gyakran valóságos tanácskozás fejlődött ki közte és a felek képviselöi között" ${ }^{80}$

A fegyelmi eljárás során a bepanaszolt bírót úgynevezett minősítő eljárásnak vetették alá. Ez egyébként nem volt szokatlan, hiszen egy-egy bíró előmenetelének megítélésénél hasonló eljárást folytattak le. A minősítő eljárásban a bíró jogismeretét, felfogását, ítélőképességét, szorgalmát, magatartását, a felekkel való előadásmódját és a vezető állásra

\footnotetext{
CSML Szegedi Ítélőtábla Elnöki iratok 13. doboz Igazságügyi Orvosi Tanács véleménye 2.

CSML Szegedi Ítélötábla Elnöki iratok 13. doboz Igazságügyi Orvosi Tanács véleménye 3.

CSML Szegedi Ítélőtábla Elnöki iratok 13. doboz.

CSML Szegedi Îtélőtábla Elnöki iratok 13. doboz.

CSML Szegedi Îtélőtábla Elnöki iratok 13. doboz Dr. Halaktovics Jenő tanúvallomása.

0 CSML Szegedi Ítélőtábla Elnöki iratok 13. doboz az ügyvéd vallomása. Hasonló megállapítást tett egy másik bírótárs, aki még hozzátette, hogy a bíró egyedül, elzárkózva élt, „fejtífusza is volt, s az okozhatta azt, hogy elhatározó és ítélkező képessége nagyon meggyengült”.
} 
való alkalmasságot vették szemügyre a felettes bíróságok. A fegyelmi eljárás alá vont bírót közepesnek minősítette mind az első, mind a másodfokú minősítő bizottság azzal a megjegyzéssel, hogy a bíró „jogismerete nem felel meg az átlagosnak”. ${ }^{81}$ A levéltárban fellelhető iratokból kiolvasható panaszok ismeretében, és annak tudatában, hogy a bíró hivatali képtelensége miatt kényszernyugdíjaztatni szándékoztak, óvatosan azt a megállapítást kell tenni, hogy egy ilyen minősítő eljárás során jogismeretét a bírónak közepesre, felfogását szintén közepesre, vezető állásra való alkalmasságát szintén közepesre értékelték, miközben az indokolásban megjegyezték, hogy jogismerete nem felel meg az átlagosnak. Miképpen lehetett a magasabb vezetői állásra való alkalmasságát közepesként értékelni? A kutatóban óhatatlanul felmerül a gyanú, hogy a fegyelmi vétséggel megvádolt bíró valószínűleg tényleg nem rendelkezett azzal a képességgel, hogy büntető ügyszakban ítélkezzen, de hagyatéki ügyek tárgyalására, esetleg telekkönyvi betétszerkesztőnek megfelelö volt. Ugyanakkor az I. világháborút követően több bírói status üres volt, mert a katonai szolgálatot töltő bírák még nem értek haza, vagy sebesülés miatt betegszabadságon voltak. Ilyen körülmények között egy vezetőnek olyan bírákra volt szüksége, akik szorgalmasan, gyorsan, kellő körültekintéssel viszik az ügyeket.

Az ügyész a bíró kényszernyugdíjazására vonatkozó kérelmét fenntartotta, és kifejtette, hogy az 1912: VII. tc. 10. \$-a szerint arra csak a bíró testi vagy szellemi fogyatkozása esetén van helye, ha ez az állapot tartósan alkalmatlanná teszi hivatali kötelezettségeinek ellátásában. „Nemcsak elmebetegség, hanem a bírói hivatal kellő ellátásához szükséges szellemi képességek, nevezetesen a kellő felfogás és ítélőképesség hiánya is értendő. [...] Hogy ez a szellemi vagy elmebeli fogyatkozás fegyelmileg vádlottban oly nagy mértékben van meg, hogy további tényleges bírói müködése nemcsak a bírói tekintély rovására szolgálna, hanem a jogkereső közönség szempontjából is sérelmes lenne, véleményem szerint az eljárás eddigi adatai nevezetesen az előző fegyelmi tárgyalások és felügyeleti intézkedések eredménytelensége, valamint a jelenlegi fegyelmi eljárás során beszerzett szakértői vélemények és tanúvallomások alapján sem lehet kétséges, a kényszernyugdíjazás [...] ezek alapján is kimondandó lett volna." ${ }^{2}$

A fegyelmi tárgyalás során az is ismertté vált, hogy hasonló panaszok miatt már 1905-ben és 1908-ban is írásbeli figyelmeztetést kapott. A vádlott tiltakozott az orvosi véleményben megfogalmazottak miatt, azt felületesnek állította. Kijelentette, hogy mind testileg, mind lelkileg frissnek, egészségesnek, munkaképesnek érzi magát. Hivatali szabálytalanságokat állítása szerint azért követett el, mert „olyan ügybeosztást kapott, melyben túl volt terhelve, s emberfeletti munkát kellett végeznie" ${ }^{83}$ Az egyik tanú azt állította, hogy nincs meg benne az ítélőbírónál feltétlenül szükséges határozottság abban, hogy a törvényt miként alkalmazza. A közvetlen felettese a fegyelmi tárgyaláskor azt mondta, hogy a büntető ügyszakot

CSML Szegedi Îtélőtábla Elnöki iratok 13. doboz Minősitő jegyzék, amelyet első fokon kir. törvényszék elnöke, másodfokon az ítélőtábla elnöke írt alá.

82 CSML Szegedi Ítélőtábla Elnöki iratok 17. sz. doboz, szegedi kir. föügyész indítványa 1921. 2.

83 CSML Szegedi Îtélőtábla Elnöki iratok 17. sz. doboz, az első fokú fegyelmi tárgyaláson tett nyilatkozata a bírónak. 
elvette tőle, és olyan feladatokkal bízta meg a járásbírót, amelyekben nem kellett közvetlenül a felekkel tárgyalni. „Ezeket az ügyeket elég jól ellátta. A vádlottal gyakran érintkezett, beszélgetett s ily alkalmakkor nála betegségre mutató szellemi képességi hiányokat nem észlelt. A vádlott [...] gyenge szellemi képességű bíró, ítélőképessége nincs, de igen szorgalmas.” ${ }^{84}$ Egy másik bíró azt állította, hogy a vádlott tárgyalásait hallgatva azt tapasztalta, hogy „emlékezőtehetsége nagyon fogyatékos, ítélőképessége nincs, erélytelen, a tárgyalásokon nem tud rendet tartani, az ügyek elintézésekor sok szabálytalanságot követ el, a hagyatéki ügyek elintézésében is követ el hibákat”. ${ }^{85}$

A fegyelmi bíróság elutasította a kényszernyugdíjazásra irányuló kérelmet, és a járásbíró ellen a fegyelmi eljárást megszüntette. A fegyelmi bíróság indokolásában kifejtette, „hogy a vádlott az átlagon aluli, korlátoltabb képességű gyenge bíró, nemcsak az orvosi véleményekkel hanem az előző fegyelmi és felügyeleti eljárások adataival az összes tanúvallomásokkal [...] is bizonyítva van, mégis a fegyelmi bíróság nézete szerint ez a szellemi fogyatkozás nem oly nagy fokú, mely miatt [...] hivatalos kötelessége teljesítésére képes egyáltalán nem lenne". ${ }^{86}$

A bíró kényszernyugdíjazására nem került sor, de a fegyelmi eljárás során a bíró ellen felhozott panaszok rövid idő múlva újból megismétlődtek, amiért később, ugyanezekért az ismételten elkövetett mulasztásokért, másik járásbíróságra helyezték át a bírót. A levéltári forrásokban megörzött vélemények, állítások alapján érezhető, hogy a kinevezett bírókat kötelezettségszegés esetében is igyekeztek a feletteseik megvédeni. A többszöri figyelmeztetés eredményezhette a bíró számára azt a hátrányt, hogy nem engedték egy magasabb fizetési osztályba lépni. Ugyanakkor az igazságszolgáltatás érdeke, a fegyelmi eljárások során készült jegyzőkönyvekből kiolvasható azon törekvés, hogy a bíróságokba vetett bizalmat meg kell őrizni, mert a jogbiztonságot is ez szolgálja, véleményem szerint azt kívánta, hogy jobb lett volna, ha az adott esetben a fegyelmi bíróság a kényszernyugdíjazás mellett dönt. Hiszen a bíró személyi anyaga megőrizte azt a tényt, hogy az új szolgálati helyén sem tudott megfelelő munkát végezni, és a kötelezettségszegései miatt a panaszok kezdődtek elölről.

\section{3. ÖSSZEFOGLALÁS}

A levéltári források alapján feltárt esetek segítségével elsődlegesen azt kívántam vizsgálni, mit tekintettek elődeink olyan kötelezettségszegésnek, amely megalapozta a fegyelmi vétség tényállását. Összességében megállapítható, hogy az esetek többségében ez konkrét mulasztást, az ügyviteli szabályok be nem tartását jelentette. Az is egyértelmü, hogy ha egy-egy alkalommal fordult elő az ilyen típusú mulasztás, akkor a hivatali megintés vagy a rosszallás törvényben meghatározott büntetését vezették be a bíró személyi lapjára.

\footnotetext{
CSML Szegedi Îtélőtábla Elnöki iratok 17. sz. doboz tárgyalási jegyzőkönyv.

85 CSML Szegedi Îtélőtábla Elnöki iratok 17. sz. doboz tárgyalási jegyzőkönyv.

86 CSML Szegedi Ítélőtábla Elnöki iratok 17. sz. doboz 1922-ben megszületett ítélet.
} 
Több esetben még ezt is soknak ítélte a fegyelmi bíróság, és ezért az 1871: VIII. tc. 28. \$-ban szabályozott „csekélyebb rendetlenség” tényét állapította meg, amely legtöbb esetben a felettes szóbeli figyelmeztetésével párosult.

Más volt a helyzet, ha többrendbeli fegyelmi vétséget, vagy olyan súlyú vétséget követett el valaki, ami már pénzbüntetéssel járt. De ehhez kellett a pénzbeli jogtalan haszonszerzés, vagy a felettes szerveknek a súlyos megsértése.

A jelenleg feldolgozott források két esetben zárultak, ha nem is a legsúlyosabb büntetéssel, a hivatalvesztéssel, hanem a nyugdíjazással. A törvény lehetővé tette a kényszernyugdíjazást is, ez történt abban az esetben, amikor bizonyítást nyert, hogy a bíró ténylegesen politikai tevékenységet folytatott, a másik esetben betegsége miatt, végül maga a bíró kérte nyugdíjazását.

A különböző eseteket összevetve azért az megállapítható, hogy a felettesek mindent elkövettek annak érdekében, hogy magát a bírót, a bírósági hivatalnokot megvédjék, ha kell, akár áthelyezéssel is. Viszont a bírói tekintélyt csorbító, a bíróságba mint az igazságszolgáltatásért felelős testületbe vetett bizalom megsértését, csorbítását, a bírói tekintély csökkentését már keményebben ítélték meg még akkor is, ha ez az utókor számára nem mindig egyértelmü.

A tanulmányban legtöbb esetben nem írtam ki a fegyelmi vétségben marasztalt bírók, bírói hivatalnokok nevét. Tettem ezt azért, mert magát a bírói felelős magatartást, a bírói kötelezettség megszegésének eseteit, azok megítélését és az azt megsértővel szemben alkalmazott eljárást kívántam feltárni. 


\section{FELHASZNÁLT IRODALOM}

1. Blutman László: A rejtélyes tiszaeszlári per. Budapest, Osiris, 2017.

2. Buzás József: Székesfehérvár és Fejér vármegye közigazgatása az 1918-1919. évi polgári demokratikus forradalom idején. In Kovács Kálmán (szerk.): Jogtudományi Értekezések 2. Budapest, ELTE, 1971.

3. Czímer Károly: A Szeged-belvárosi Kaszinó százéves története (1829-1929). Szeged, Szeged-belvárosi Kaszinó, 1929.

4. Homoki-Nagy Mária: A bírói felelősség az 1869:IV. tc. alapján. Acta Universitatis Szegediensis: Forum: Acta Juridica et Politica, 7. (2017), 1. 45-68.

5. Máthé Gábor: A magyar burzsoá igazságszolgáltatási szervezet kialakulása 1867-1875. Budapest, Akadémiai Kiadó, 1982.

6. Márkus Dezső: A bírói felelősségről szóló törvény módosítása. Jogtudományi Közlöny, (1909), 41. 354-359.

7. Navratil Szonja: A jogászi hivatásrendek története Magyarországon (1868/1869-1937). Budapest, ELTE Eötvös, 2014.

8. Neumann Jenő: Szarvas nagyközség története; az új Szarvas alapitásának 200 éves jubileuma. Szarvas 1922. Elérhetö: https://rchive.org/stream/szarvasnagykzs00neum/ szarvasnagykzs00neum_djvu.txt (A letöltés dátuma: 2018. 03. 28.)

9. Papp László: A bírák fegyelmi felelőssége a polgári korban. Kézirat.

10. Patyi Zsófia: A bírák fegyelmi felelősségének bő évszázados alakulása I. (1868-1954). Acta Juridica et Politica: Forum Publicationes Doctorandorum Juridicorum, 6. (2016), 147-164.

11. Stipta István: A magyar bírósági rendszer története. Debrecen, Multiplex Media, 1997.

12. Stipta István: A tiszaeszlári per és a korabeli büntető eljárásjog. Jogtörténeti Szemle, (2012), 4. 22-34.

13. Székely Miksa: A bírák és bírói hivatalnokok felelősségéről szóló törvényjavaslat. Magyar Jogászegyleti Értekezések, XLIII. 5. (1889), 2.

14. Tóth Lörinc (szerk.): A birói felelösségi törvény az országgyülésen s az ügyvédi egyletekben.

Jogi források

1. 1869. évi IV. törvénycikk a birói hatalom gyakorlásáról

2. 1871. évi VIII. törvénycikk a birák és birósági hivatalnokok felelősségéről

3. 1879. évi XL. törvénycikk a magyar büntetö törvénykönyv a kihágásokról

4. 1912. évi VII. törvénycikk egyes igazságügyi szervezeti és eljárási szabályok módosításáról

5. 1920. évi XV. törvénycikk az árdrágító visszaélésekről

Levéltári forrás

1. Magyar Nemzeti Levéltár Csongrád Megyei Levéltára (CSML) VII. 1. 1891-1950, Szegedi Ítélőtábla Elnöki iratok VII. 1. 
Prof. Dr. Homoki-Nagy Mária egyetemi tanár a SZTE Állam- és Jogtudományi Kar Magyar Jogtörténeti Tanszék vezetője. A szerző a magyar magánjogi jogintézmények történeti hátterét kutatja, elsősorban a 18-19. század gazdasági, történeti hátterét is figyelembe véve. Mindez kiegészül a magyar magánjogi kodifikáció történetének elemzésével, amely szükségessé teszi az I. világháborút követő változások vizsgálatát, különös tekintettel a háborúnak a magánjogi intézményekre gyakorolt hatására. Ehhez kapcsolódva elemzi az Osztrák Polgári Törvénykönyv hatását a magyar jogéletre. Az utóbbi idők bíróságtörténeti kutatásaiba bekapcsolódva, a Szegedi Törvényszék és a Szegedi Ítélőtábla történetén belül, az egyes bírák szerepét, a bírói összeférhetetlenséget, a bírói felelősségen belül a fegyelmi vétségekkel összefüggő eljárásokat és a törvényszék magánjogi joggyakorlatát kutatja. Tagja a jogi néprajz - jogi kultúrtörténeti kutatócsoportnak, amelynek keretein belül a szokásnak, a jogszokásnak és a szokásjognak a szerepét elemzi a magánjog területén. 